\title{
Forest Carbon Management: a Review of Silvicultural Practices and Management Strategies Across Boreal, Temperate and Tropical Forests
}

\author{
Abderrahmane Ameray ${ }^{1,2}$ (I) $\cdot$ Yves Bergeron ${ }^{1,2} \cdot$ Osvaldo Valeria ${ }^{1,2,3} \cdot$ Miguel Montoro Girona $^{1,2,4} \cdot$ Xavier Cavard $^{1,2}$
}

Accepted: 25 October 2021 / Published online: 15 November 2021

(c) The Author(s) 2021

\begin{abstract}
Purpose of Review Carbon sequestration and storage in forest ecosystems is often promoted as a solution for reducing $\mathrm{CO}_{2}$ concentrations in the atmosphere. Yet, our understanding is lacking regarding how forest management strategies affect the net removal of greenhouse gases and contribute to climate change mitigation. Here, we present a review of carbon sequestration and stock dynamics, following three strategies that are widely used in boreal, temperate and tropical forests: extensive forest management, intensive forest management and old-growth forest conservation.

Recent Findings Several studies show that specific forest management strategies can improve carbon sequestration capacity and soil carbon storage. Within these studies, the old-growth forest conservation strategy results in greater carbon storage in soils than do extensive and intensive forest management. Intensive forest management enhances forest carbon sequestration capacity through afforestation using fast-growing species, mechanical soil preparation from low to moderate intensity and $\mathrm{N}$ fertilization. Extensive forest management is an intermediate compromise regarding carbon sequestration and soil carbon storage, between conservation and intensive forest management strategies. With respect to silvicultural treatments, partial cutting is a practice that increases forest carbon sequestration rates and maintains higher carbon storage in soils compared to clear-cuts. Each silvicultural practice that is discussed in this review showed a similar effect on forest carbon in all biomes, although the magnitude of these effects differs mainly in terms of heterotrophic respiration.

Summary To achieve sustainable management and fulfill industrial demand and profitability, specific gaps must be dealt with to improve our scientific knowledge regarding forest carbon sequestration in a climate change context, mainly through the integration of the three aforementioned strategies in a functional zoning approach at the landscape scale. We present a review with promising strategies for guiding sustainable forest management in such a global context.
\end{abstract}

Keywords Carbon sequestration and storage $\cdot$ Sustainable forest management $\cdot$ Silviculture $\cdot$ Climate change $\cdot$ Partial harvest

$\begin{array}{ll}\text { Abbreviations } \\ \text { C } & \text { Carbon } \\ \text { CC } & \text { Clear-cutting } \\ \text { CSS } & \text { Carbon sequestration and storage }\end{array}$

This article is part of the Topical Collection on Climate Change and Carbon Sequestration

Abderrahmane Ameray

amea02@uqat.ca

1 Institut de recherche sur les forêts, Université du Québec en Abitibi-Témiscamingue (UQAT), 445 boul. de l'Université, Rouyn-Noranda, QC J9X 5E4, Canada

2 Centre d'étude de la forêt, Université du Québec à Montréal, Succ. Centre-ville, Montréal, QC C.P. 8888H3C 3P8, Canada
EFM Extensive forest management

FMS Forest management strategies

GPP Gross primary production

HWP Harvested wood products

IFM Intensive forest management

MSP Mechanical soil preparation

NEP Net ecosystem production

3 Hémera Earth Observation Center, School of Forest Engineering, Faculty of Sciences, Santiago, Universidad Mayor, 8580745 Huechuraba, Chile

4 Restoration Ecology Research Group, Department of Wildlife, Fish and Environmental Studies, Swedish University of Agricultural Sciences (SLU), 90736 Skogsmarksgränd, Umeå, Sweden 


$\begin{array}{ll}\text { NPP } & \text { Net primary production } \\ \text { PC } & \text { Partial cuts } \\ \text { PCT } & \text { Pre-commercial thinning } \\ R_{\mathrm{a}} & \text { Autotrophic respiration } \\ R_{\mathrm{h}} & \text { Heterotrophic respiration } \\ \text { SOC } & \text { Soil organic carbon }\end{array}$

\section{Introduction}

Forest ecosystems offer crucial and diverse services to societies around the world, by acting as primary habitats for a wide range of species, supplying wood, supporting biodiversity maintenance and conservation and being indispensable to both indigenous societies and the overall maintenance of human health [1]. Second only to the oceans, world forests play a major role in the carbon (C) cycle as they account for a greater part of $\mathrm{C}$ exchange between the atmosphere and terrestrial biosphere than do other land biomes, thereby contributing to climate change mitigation [2•,3]. Forest ecosystems store more than $80 \%$ of all terrestrial aboveground $\mathrm{C}$ and more than $70 \%$ of all soil organic carbon (SOC) [4]. In 2011, world forest C stocks were estimated to be $861 \mathrm{Pg}$, where soil to a depth of $1 \mathrm{~m}$ constituted the main pool (44\%), followed by biomass (42\%), deadwood (8\%) and litter (5\%) [2•]. Between 1990 and 2015, this stock declined by $13.6 \mathrm{Pg}$; most of this decline has occurred in living biomass and soils, and mainly in tropical forests [5]. Recently published work has indicated that world forest ecosystems remove nearly $2 \mathrm{Pg} \mathrm{year}^{-1}$ of $\mathrm{C}$ from the atmosphere through net growth, thereby absorbing about $30 \%$ of anthropogenic $\mathrm{CO}_{2}$ emissions [5], [6].

For the purpose of this review, we have divided forest management practices and strategies between intensive and extensive forest management. Intensive forest management (IFM) is a strategy that is widely used to increase productivity and timber quality in the shortest period to meet growing industrial needs and increase profitability [[7]•]. To achieve potential site productivity, IFM is based upon several practices including planting, genomic improvement, site preparation, fertilization, enhanced protection and silvicultural treatments, which depend upon the frequency and intensity of harvesting during the rotation [7•]. In contrast, an extensive forest management (EFM) strategy has been defined as "the practice of forestry on a basis of low operating and investment costs per acre" [8]. EFM involves the use of modified cuts (partial cuts and selective cutting) and other silvicultural treatments to promote natural regeneration [ $7 \bullet]$. Furthermore, EFM that is based upon moderate harvesting intensities and long rotations could be used not only to increase $\mathrm{C}$ storage, but also to provide other economic and ecosystem services [9]. However, Irland [7•] noted several broad contrasts between the ends of the spectrum of intensive versus extensive forest management: (a) IFM uses an even-aged structure with single species and is characterized by short rotations, (b) whereas EFM is based upon a multiple-age structure, with or without mixtures, and is characterized by longer rotations. The concept of EFM is also different from that of the ecosystem-based management approach, in that the latter aims to maintain forest composition and structure in an attempt to emulate natural disturbance regimes and natural vegetation patterns [10]. IFM and EFM strategies could be represented in the form of an ecological gradient that ranges from a state that is considered to be natural to a state that is considered to be artificial, which is strictly artificial in the case of IFM and natural or semi-natural in the case of EFM. The two strategies represent a gradient ranging from intensive (plantation) to extensive management and from lower to high harvesting intensity and rotation length.

Earth's human population has reached 7.7 billion and is expected to reach 9.2 billion by 2050 [11]. Global population increase and land use expansion to supply human demands for wood products and other services are the main challenges of forest management [12] and one of the main causes of deforestation (e.g. forest conversion to agricultural land and urban areas). The three major forest biomes are tropical, temperate and boreal forests. These biomes mostly occur at different latitudes and experience different climatic conditions with a large community of vegetation. Over 25 years (1990 to 2015), global forest area decreased from 4.128 to 3.999 Gha [13]. The vast majority of forest loss has been observed in the tropics, where the rate of loss fell by $39 \%$, from 10.4 Mha year $^{-1}$ in the 1990s to $6.4 \mathrm{Mha} \mathrm{year}^{-1}$ from 2010 to 2015 [13]. Over the same period, boreal forests showed an increase in area, while temperate forests had a lower deforestation rate $(-0.01 \%)$, compared to tropical forests [14]. The recent Food and Agriculture Organization (FAO) report showed that between 2015 and 2020, the world rate of deforestation was estimated at $10 \mathrm{Mha} \mathrm{year}^{-1}$, down from $16 \mathrm{Mha} \mathrm{year}^{-1}$ in the 1990s [14]. Yet, maintaining and enhancing forest ecosystem carbon sequestration and storage (CSS) is progressively becoming a fundamental goal for sustainable forest management [15••]. In fact, according to the Kyoto Protocol and United Nations Framework Convention on Climate Change (UNFCCC), the potential mitigation of forest ecosystems ( $\mathrm{C}$ sequestration) makes $\mathrm{C}$ management a promising solution to climate change $[15 \bullet \bullet],[16 \bullet \bullet]$.

Afforestation and old-growth forest conservation are natural means of countering deforestation. Indeed, some authors have proposed that old-growth forests should be left intact and conserved, given that they continue to conserve considerable 
quantities of $\mathrm{C}$, which is stored in aboveground biomass and the soil [17••]. In contrast, others have asserted that in younger managed forests, the $\mathrm{C}$ sequestration rate is much higher than in old-growth forests; by increasing harvesting, all at once, C storage in harvested wood products (HWP) would increase [18], [19]. Recent work also has demonstrated that adaptive silviculture practices (e.g. less intensive harvesting) could be among those strategies that would increase long-term CSS, in both ecosystems and HWP [19], [20••], [21]. Thus, it seems that forests can be managed to mitigate global change through three major, non-mutually exclusive strategies: (1) preserving existing forest $\mathrm{C}$ stocks through conservation, mainly of the old-growth forest, (2) using EFM that is based upon partial cuts (PC) and selective cutting to increase natural forest productivity and preserve parts of the existing forest $\mathrm{C}$ stocks [22], [23], [24•] and (3) achieving high productivity through IFM practices (e.g. afforestation, fertilization, genomics) [25], [26]. These forest management strategies (FMS) must take into consideration all possible ecosystem services, from environmental, economic and social perspectives.

Climate change over the coming decades is expected to exert substantial effects on forest ecosystems worldwide [26]-[28]. Consequently, the development of FMS that would increase forest $\mathrm{C}$ sequestration capacity is becoming a priority for forest management around the globe. Yet, integrating CSS into FMS is a challenging prospect for forest managers who have not traditionally included environmental issues among their objectives. The main goal of this review is to synthesize the most relevant information about three globally used FMS (EFM, IFM and old-growth forest conservation) that can be used (separately or combined) to enhance $\mathrm{C}$ sequestration in living biomass and SOC storage at the landscape scale, which would subsequently provide instructions and recommendations for managers. First, we briefly recall the general principles of the forest $\mathrm{C}$ cycle, and the resulting patterns of $\mathrm{C}$ allocation in boreal, temperate and tropical forest ecosystems. Second, we review the effects of different IFM practices on CSS, mainly fertilization, mechanical site preparation, genetic improvement and afforestation. Third, we assess the contrasting effects of IFM and EFM practices on CSS, including silvicultural treatments (e.g. thinning, clear-cuts, partial cuts) and system structures (even-aged/uneven-aged, monoculture/mixtures). Particular emphasis has been placed on old-growth forest conservation to build up SOC stocks. World forest ecosystems are considered as nature-based climate solutions and present exciting opportunities for the private and public sectors to meet their climate goals. This review gathers and provides relevant information to guide sustainable management and implement participatory decision-making in forest planning under global changes.

\section{Boreal, Tropical and Temperate Forest Carbon Cycles: Mechanisms and Allocations}

\section{General Forest Carbon Cycle}

The forest $\mathrm{C}$ cycle is characterized by a biological component (forest ecosystem) and an industrial component (forest products) (Fig. 1) [19], [29]. The forest $\mathrm{C}$ cycle is generally assessed and monitored by estimating the following: gross primary production (GPP), autotrophic respiration $\left(R_{\mathrm{a}}\right)$ (comprised of maintenance and growth respiration), net primary production (NPP) (Eq. 1), heterotrophic respiration $\left(R_{\mathrm{h}}\right)$ and net ecosystem production (NEP) (Eq. 2) [18], [30]. At the same time, HWP could be integrated into this assessment through lifecycle analyses to evaluate the forest sector's net C balance [19], [29]. The biological C cycle is driven by several climatic parameters (e.g. temperature, precipitation) [31] and is influenced by land use and management through natural disturbances and a variety of anthropogenic actions such as afforestation, deforestation, fertilization, irrigation and harvesting [20••], [21], [32]. In the industrial cycle, HWP is considered by the Intergovernmental Panel on Climate Change (IPCC) to be a significant loss of $\mathrm{C}$ from forest ecosystems and may remain outside the ecosystem boundaries for a variable period of time. The $\mathrm{C}$ that is stored in timber or furniture can remain sequestered for a very long time, while the $\mathrm{C}$ in fuelwood results in an immediate emission [19], [29]. HWP contributions to C storage and emissions depend upon their life cycles [20••]. Worldwide, the annual HWP potential for $\mathrm{C}$ sequestration is about $2.8 \mathrm{Pg} \mathrm{year}^{-1}$, with contributions of $1.8 \mathrm{Pg} \mathrm{year}^{-1}$ (64\%), $0.7 \mathrm{Pg}_{\text {year }}{ }^{-1}$ (25\%) and $0.3 \mathrm{Pg} \mathrm{year}^{-1}(11 \%)$ from tropical, temperate and boreal forests, respectively (Fig. 1) [33].

$$
\begin{aligned}
& \mathrm{NPP}=\mathrm{GPP}-R_{\mathrm{a}} \\
& \mathrm{NEP}=\mathrm{NPP}-R_{\mathrm{h}}
\end{aligned}
$$

\section{Forest Carbon Cycle Under Different Climates}

There are three major forest types: boreal, temperate and tropical. According to the recent assessment report of FAO [14] and Keenan et al. [13], (i) boreal forests occupy much of the circumpolar region between $50^{\circ}$ and $70^{\circ} \mathrm{N}$ and are considered as the world's second-largest forest biome with an area of 12.2 million $\mathrm{km}^{2}$ (27\% of world forest in 2020); $43 \%$ of this area is in Siberia, 36\% is in North America and $21 \%$ is in Europe. This forest provides 37\% of global wood consumption [34•], [35••], [36]. The dominant genera in the boreal biome are Picea, Pinus, Abies, Populus and Betula. 


\section{Forest Carbon cycle}

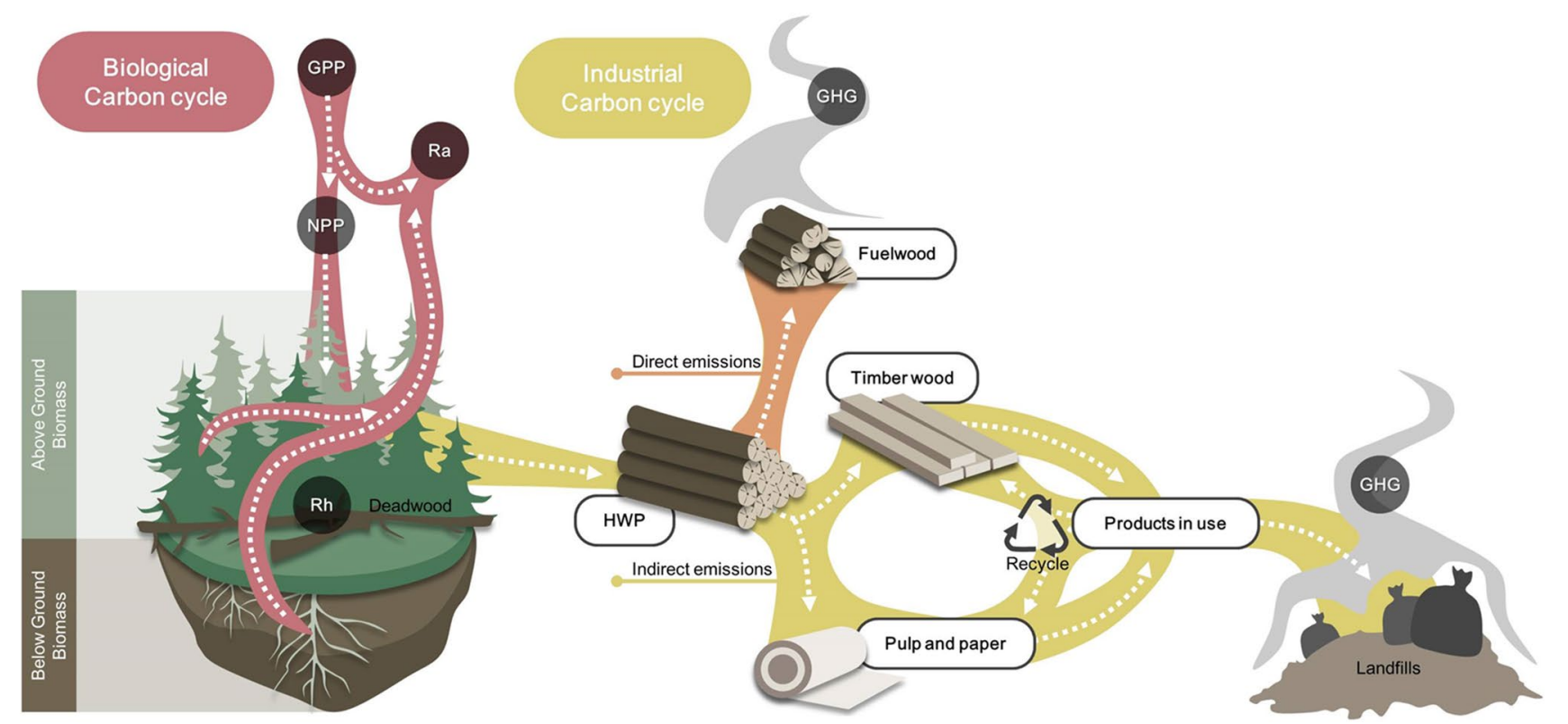

Fig. 1 Forest carbon cycle and biological and industrial components, including gross primary production (GPP), net primary production (NPP), autotrophic respiration $\left(R_{\mathrm{a}}\right)$, heterotrophic respiration $\left(R_{\mathrm{h}}\right)$

(ii) Of the 25 to 33 million $\mathrm{km}^{2}$ of forests covering the globe, about 6.9 million $\mathrm{km}^{2}$ (16\% of world forests in 2020) is temperate forests, which are found between the tropical and boreal regions. These forests cover both hemispheres at latitudes ranging from 25 to $50^{\circ}$. In this biome, the dominant tree genera include broadleaved deciduous (e.g. Fagus, Acer, Fraxinus and Quercus) and needle-leaved evergreen (e.g. Picea, Abies, Pinus) [37]. (iii) In contrast, almost half of the world's forested areas consist of tropical forests (47\%) [14]. The tropical rainforests, which globally constitute one of Earth's largest biomes (major life zones), are dominated by broad-leaved trees that form a dense upper canopy (layer of foliage) and contain a diverse array of tree species (more than 20,000 species have been observed) (e.g. Ceiba, Cecropia, Agathis) [38]. Those forests grow mainly in three regions: the Malesian botanical subkingdom, tropical South and Central America (especially the Amazon Basin) and West and Central Africa [38].

\section{Biomass Carbon Pool}

GPP, NPP, $R_{\mathrm{a}}$ and $R_{\mathrm{h}}$ of boreal evergreen forests are 873

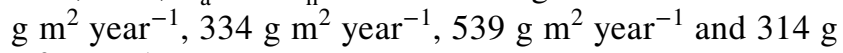
$\mathrm{m}^{2}$ year ${ }^{-1}$, respectively. For the same parameters, values

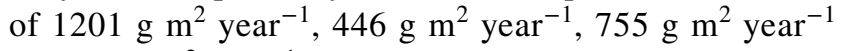
and $275 \mathrm{~g} \mathrm{~m}^{2}$ year $^{-1}$ were estimated respectively in boreal and harvested wood products (HWP). HWP greenhouse gases (GHG) emissions depend upon their life cycles and uses, [29][19] adapted from Gower and Smyth et al.

deciduous forests (Fig. 2) [35••]. With an average GPP exceeding $3000 \mathrm{~g} \mathrm{~m}^{-2}$ year ${ }^{-1}$ in tropical evergreen and deciduous stands, those forest ecosystems have greater $\mathrm{C}$ sequestration capacity, despite also having higher average values of $R_{\mathrm{a}}$ and $R_{\mathrm{h}}\left(>2000 \mathrm{~g} \mathrm{~m}^{-2}\right.$ year $^{-1}$ ) (Fig. 2). These respiratory demands can reduce the tropical forest NEP substantially $[35 \bullet \bullet]$. In contrast, temperate evergreen and deciduous forests respectively sequester $811 \mathrm{~g} \mathrm{~m}^{2}$ year $^{-1}$ and $702 \mathrm{~g} \mathrm{~m}^{2}$ year $^{-1}$ [35••], [39]. Temperate evergreen forest $R_{\mathrm{a}}$ and $R_{\mathrm{h}}$ values are $951 \mathrm{~g} \mathrm{~m}^{-2}$ year $^{-1}$ and $420 \mathrm{~g}$ $\mathrm{m}^{-2}$ year $^{-1}$, correspondingly, while deciduous forest $R_{\mathrm{a}}$ and $R_{\mathrm{h}}$ estimates are $673 \mathrm{~g} \mathrm{~m}^{2}$ year ${ }^{-1}$ and $387 \mathrm{~g} \mathrm{~m}^{2}$ year ${ }^{-1}$, respectively (Fig. 2). However, the total $\mathrm{C}$ sink of boreal forests is about $0.50 \mathrm{Pg} \mathrm{year}^{-1}$, lower than that observed in temperate $\left(0.72 \mathrm{Pg} \mathrm{year}^{-1}\right)$ and tropical (1.2 $\left.\mathrm{Pg} \mathrm{year}^{-1}\right)$ biomes [34•]. Boreal forest ecosystems store $88 \mathrm{Pg}$ of C in living biomass (aboveground and belowground), which is higher than that observed in temperate forests $(59 \mathrm{Pg})$ and lower than that estimated for tropical forests $(212 \mathrm{Pg})$ [34•]. The tropical forests, on average, can store $50 \%$ more $\mathrm{C}$ in the trees than any other type of forest [2•]. These forests hold more $\mathrm{C}$ in their biomass than do temperate and boreal forests combined, but the high rates of deforestation that they are currently experiencing will likely cause more $\mathrm{C}$ to be released into the atmosphere (1-2 $\mathrm{Pg} \mathrm{year}^{-1}$ ) [40]. 


\section{Soil Carbon Pool}

Despite the lower observed C storage in living biomass in boreal forests, they store $471 \mathrm{Pg}$ in soil, which is a very high value compared to tropical (216 Pg) and temperate (100 $\mathrm{Pg}$ ) ecosystems [34•]. Boreal forest soils store $60 \%$ of the world's SOC [2•]. The C distribution in common boreal forest soils has been described by Deluca and Boisvenue [36]; Cambisols and Podzols house $5-40 \mathrm{Mg} \mathrm{ha}^{-1}$ of $\mathrm{C}$ in the $\mathrm{O}$ horizon, and about $10-90 \mathrm{Mg} \mathrm{ha}^{-1}$ in surface mineral soils $(0-15 \mathrm{~cm})$. An additional $10-150 \mathrm{Mg} \mathrm{ha}^{-1}$ is stored at $15-45$ $\mathrm{cm}$ depths in upland forest soils, while there is generally little C below $1 \mathrm{~m}$ in upland soils [36], [42•]. Yet, boreal forest stores more $\mathrm{C}$ in organic soil (84\%) than in living biomass (16\%), while $55 \%$ of $\mathrm{C}$ in temperate and tropical forests is stored in living biomass [34•]. During a 17-year period (1990-2007), SOC stocks in boreal and temperate forests increased by $4.5 \%$ and $7.6 \%$, respectively, as forest area expanded following agricultural abandonment and immature forests grew with reduced harvesting. Meanwhile, SOC in tropical forests declined by $7.7 \%$, which was caused by deforestation within intact tropical forests [43].

\section{Boreal Peatland Carbon}

Peatlands occupy about $4 \%$ of the global land surface and are located mainly in the boreal biome; they store about $30 \%$ of global SOC [42•]. In addition to boreal C storage in biomass and soil pools, boreal peatlands contain an additional soil C stock of 260-600 Pg [[44]]. Yet, forested peatlands have a lower $\mathrm{C}$ sequestration potential $\left(15.9 \mathrm{~g} \mathrm{~m}^{-2} \mathrm{year}^{-1}\right.$, averaged over six peatland study sites) compared to natural

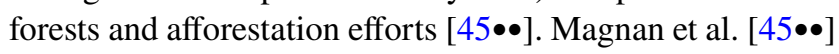
noted that the quantity of $\mathrm{C}$ stored in the peat at 50-350 $\mathrm{cm}$ depths $\left(62-172 \mathrm{~kg} \mathrm{~m}^{-2}\right)$ greatly exceeds aboveground tree biomass $\mathrm{C}\left(1.5-5.3 \mathrm{~kg} \mathrm{~m}^{-2}\right)$, while the organic layer $(\leq 30 \mathrm{~cm})$ in adjacent paludified stands holds around twice as much $\mathrm{C}$ as does the live biomass. Under climate change, Lavoie et al. [42•] have suggested that most northern forested peatlands (located in eastern Canada, Alaska, Russia and Fennoscandia) will continue acting as $\mathrm{C}$ sinks for the foreseeable future, given that precipitation is expected to increase in these areas. In contrast, $\mathrm{C}$ sequestration rates in forested peatlands of Western and Central Canada will decline, thereby becoming potential $\mathrm{C}$ sources, since precipitation is predicted to decrease [42•].

The dynamics of $\mathrm{C}$ budgets differ considerably among biomes (Fig. 2). Tropical forests sequester more $\mathrm{C}$ (high GPP, $3351 \mathrm{~g} \mathrm{~m}^{2}$ year $^{-1}$ ) than temperate forests, but their estimates of $R_{\mathrm{h}}$ and $R_{\mathrm{a}}$ are very high, given the long grow-

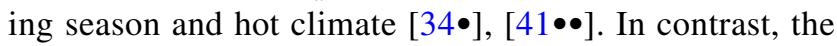
boreal forest is characterized by a cold climate and a short growing season, which results in a lower $\mathrm{C}$ sequestration capacity, together with slow decomposition and growth rates [41••]. The highest NEP values are observed in temperate forests (> $200 \mathrm{~g} \mathrm{~m}^{2}$ year $^{-1}$ for both coniferous and broadleaf forests); this may be related to forest management, which is more intensive in this biome and aims to increase the

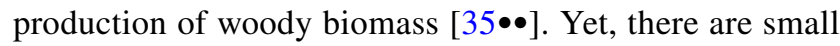
differences among these biomes in terms of $\mathrm{C}$ sequestration efficiency. For instance, if we calculate production efficiency (NPP/GPP) for the evergreen forests, as defined by Goulden et al. [18], we find efficiency values of $34 \%, 38 \%$ and $46 \%$ for tropical, boreal and temperate forests (Fig. 2), respectively. Nevertheless, these differences in $\mathrm{C}$ dynamics may affect the ability of FMS to increase $\mathrm{C}$ sequestration and storage for each biome.

\section{Impacts of Forest Management Strategies on Carbon Dynamics}

\section{Intensive Forest Management}

\section{Genetic Improvement}

Given that the primary metric of a forest's value has been its merchantable volume, plantation forestry that is based upon successful breeding of superior tree genotypes (fastgrowth species) is becoming used more widely to maximize productivity [16••], [26], [41••]. Selection for fast-growing genotypes may generally increase $\mathrm{C}$ sequestration rates by approximately 10 to $20 \%$, depending upon what species is being grown [46]. Douglas-fir (Pseudotsuga menziesii [Mirb.] Franco) is grown as a plantation species in Europe, South America, New Zealand and Australia, and throughout its extensive natural range in western North America. Chappell et al. [47] reported that Douglas-fir growing on a good site (site index $=32 \mathrm{~m}$ ) would be expected to yield $174 \mathrm{~m}^{3}$ $\mathrm{ha}^{-1}$ at the end of a 50 -year rotation if they were naturally regenerated. Through a similar site regeneration process using genetically improved stock, which was subsequently thinned and fertilized, Douglas-fir can produce $643 \mathrm{~m}^{3} \mathrm{ha}^{-1}$ in 50 years [47]. In Canada, boreal forest hybrid poplar clones (e.g. Populus balsamifera L. $\times$ P. simonii Carrière, $P$. deltoides $\times P . \times$ petrowskyana) are generally selected for $C$ uptake because of their rapid rates of growth [48]. In addition, there is a difference between monoclonal and polyclonal cultures, in terms of growth and tree size, thereby affecting the $\mathrm{C}$ stock in the aboveground biomass [48], [49]. Elferjani et al. [49] showed that the stem volume of hybrid poplar in a monoclonal culture is $6.1 \mathrm{~m}^{3} \mathrm{ha}^{-1}$, while it is $21 \%$ higher in a polyclonal culture $\left(7.4 \mathrm{~m}^{3} \mathrm{ha}^{-1}\right)$. Fast-growing tree species typically sequester more $\mathrm{C}$ at a young age, whereas $\mathrm{C}$ sequestration rates for slow-growing trees may 


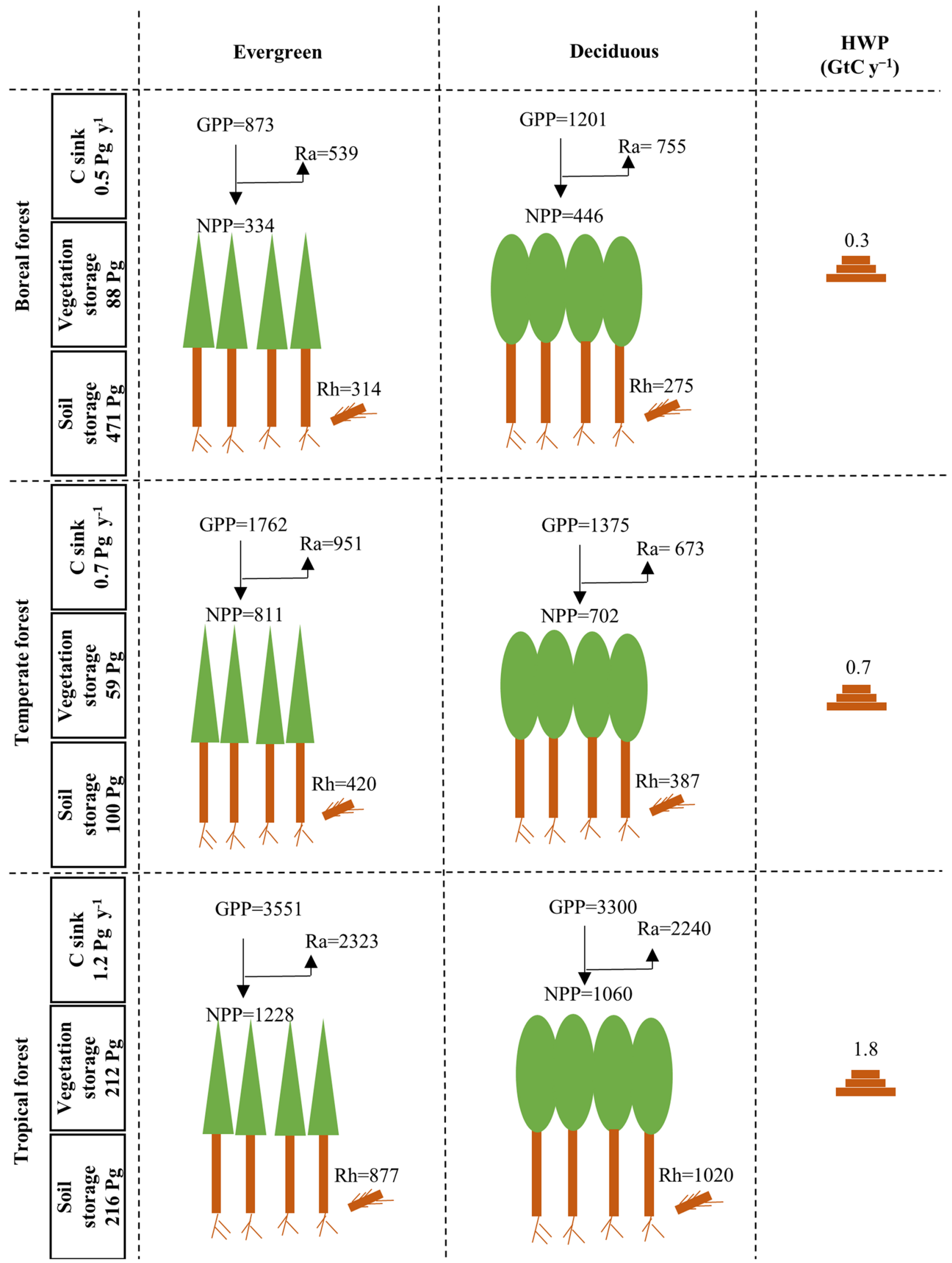


4Fig. 2 Carbon sequestration and storage in the boreal, temperate and tropical forests, together with estimates of important carbon cycle components: gross primary production (GPP), net primary production (NPP), autotrophic respiration $\left(R_{\mathrm{a}}\right)$ and heterotrophic respiration $\left(R_{\mathrm{h}}\right)$, estimated in $\mathrm{g} \mathrm{m}^{-2}$ year $^{-1}$. Estimated values are [32], [33], [34•],

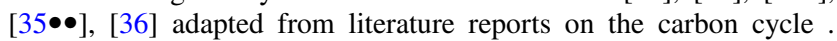
They require careful scaling up over very heterogeneous forest landscapes. In fact, there is a substantial variation among the geographic regions within each biome

reach a peak after many years have elapsed, depending on growth rate patterns and rotation length [25].

Today, the main issues of concern around the application of genetic engineering in forestry are about native biodiversity and the provision of ecosystem services. Using such techniques may reveal several drawbacks, such as less genetic diversity, invasive behaviour and less favourable habitat than natural forests [50]. Maintaining natural patterns of heterogeneity, including species diversity, across spatial and temporal scales is consistent with current principles of ecosystem management. The risk assessment of using such techniques is considered important and should include aspects such as the evaluation of the probability of establishment, spread and related undesirable consequences of establishing species that have been improved genetically [51]. Given the complex nature of the risks, Mathews and Campbell [51] state that an interdisciplinary approach including ecologists and molecular biologists is required.

\section{Fertilization}

The most critical elements for forest NPP are macro-nutrients ( $\mathrm{N}, \mathrm{P}, \mathrm{K}, \mathrm{Mg}$ and $\mathrm{Ca}$ ). Both $\mathrm{N}$ and $\mathrm{P}$ are particularly important nutrients for ecosystem structure, processes and function, since their absence limits the production of plant biomass and growth. From previous work, $\mathrm{N}$ has been found to limit forest NPP on relatively young soils, whereas P is limiting on old soils [[52]]. Economically optimal intensive fertilization increased timber supply by $20 \%$ [47], [53], [54]. Fertilization is usually associated with forest plantations, especially those composed of conifer species, such as Douglas-fir, spruce (Picea spp.) or maritime pine (Pinus pinaster Aiton); supplemental nutrient applications can dramatically increase forest $\mathrm{C}$ sequestration capacity [54]-[56]. For instance, Jassal et al. [56] found that fertilization of 58 -year-old Douglas-fir stands with $200 \mathrm{~kg} \mathrm{ha}^{-1}$ of urea-Nelevated NEP by $64 \%$, i.e. NEP increased from 326 to $535 \mathrm{~g}$ $\mathrm{m}^{-2}$ of C. Generally, nutrient limitation can reduce leaf area index (LAI), photosynthetic capacity or both [[52]]. Higher soil nutrient contents could increase soil decomposition and microbial activity, thereby decreasing SOC in the short term [57]; SOC could increase in the long term, since fertilization increases vegetation growth. Yet, $\mathrm{N}$ fertilization has been demonstrated to be the only forest management practice that has had a positive effect on the soil $\mathrm{C}$ pool, mainly in the mineral soil (A horizon) [58]. Many recent studies also have demonstrated that fertilization of temperate and boreal forests has a high potential for reducing ecosystem respiration $\left(R_{\mathrm{h}}\right.$ and $\left.R_{\mathrm{a}}\right)$ [54]. Nevertheless, in boreal forests as the growing season is likely to be prolonged by ongoing climate change, this would lead to higher $\mathrm{N}$ demand. $\mathrm{N}$ can be supplied by atmospheric deposition, but deposition is unlikely to cover the $\mathrm{N}$ demand at the appropriate rate, particularly in boreal forests where the inputs are lower [59] and tend to be intercepted by the thick bryophyte groundcover [60], [61]. Beyond macro-nutrients, forest $\mathrm{C}$ sequestration capacity may be limited by deficiencies of some trace elements, such as $\mathrm{Fe}, \mathrm{Cu}$ and $\mathrm{Zn}$ [55].

The fertilization timing and frequency generally depend upon the site nutrient content and the planted species (broadleaves vs. coniferous) [53]. In contrast, the application of fertilizers releases nutrients (including phosphate $\mathrm{P}$ ) to the freshwater bodies that contribute to their eutrophication (accumulation of minerals and nutrients), particularly nearby rivers or lakes [62]. However, in order to both improve forest $\mathrm{C}$ sequestration capacity and reduce environmental pollution, appropriately balanced fertilization is required.

\section{Mechanical Soil Preparation}

Forest $C$ sequestration capacity can be significantly enhanced by careful mechanical soil preparation (MSP) prior to afforestation or following forest harvesting. Scarification, mounding, sub-soiling/ripping and deep soil cultivation (ploughing to $50 \mathrm{~cm}$ depth) are common MSP treatments that are used in forestry. Superficial cultivation of soil layers could be included among those treatments, since this process aims to remove competing vegetation and logging slash, to facilitate planting or direct seeding [63], [64•]. MSP is carried out for many reasons: to promote natural regeneration, to reduce competition between tree seedlings and understory vegetation, to create micro-sites that favour seedling survival and to enhance forest growth by increasing nutrient content, and element mobilization in soils [55], [61], [64•].

MSP techniques could also temporarily reduce soil C stocks for the short or medium term, since they can increase decomposition rates $[65 \bullet \bullet$. Nevertheless, the real effect of MSP on forest soil $\mathrm{C}$ depends upon the methods that are used and their intensities [63], [64•]. For instance, Jiménez Esquilín et al. [66] noted that soil C (O horizon and uppermost mineral soil) had decreased by $50 \%$, as measured 24 years after scarification. Nordborg et al. [63] asserted that no differences emerged among MSP treatments when the whole soil profile was considered; however, losses were higher in the $\mathrm{O}$ horizon after patch scarification (5 $\mathrm{cm}$ deep) compared to deep-soil cultivation. Also, Mjöfors et al. [[67]••] demonstrated that site preparation increases forest ecosystem 
C stocks over the long term. They further recommended mounding or disc trenching to promote $\mathrm{C}$ sequestration, since these treatments did not affect soil $\mathrm{C}$ stocks down to a depth of $30 \mathrm{~cm}$. Consequently, low- or moderate-intensity MSP techniques had no appreciable effect on soil $\mathrm{C}$, but increased the volume of soil that roots can readily exploit by decreasing bulk density. Therefore, these treatments enhanced forest productivity, leading to greater litter production, thereby increasing soil $\mathrm{C}$ content over the long term [63], [64•], [68], [69]. In previous studies, roots have been shown to concentrate in micro-sites with mixed soil organic matter and mineral soil in a deep cultivated soil profile [69]. If the organic material is ploughed into the mineral soil, water relations are often improved by higher infiltration capacity so that moisture is preserved, thereby enhancing forest NPP [68].

By contrast, intensive MSP treatments are recommended in wetland soils, since these enhance tree establishment, lower the water table and increase oxygenation of the soils [20••], [42•]. All MSP techniques definitely reduce soil C sequestration and turn peatlands into significant $\mathrm{C}$ sources, because of the high rates of decomposition. Moreover, MSP reduces the water content while improving soil and root aeration, thereby enhancing tree productivity and increasing ecosystem $R_{\mathrm{h}}$ [42•], [70]. Yet, Lavoie et al. [42•] have stressed that in peatlands where wildfires are severe and frequent, MSP could become problematic for future $\mathrm{C}$ emissions. Nevertheless, peatlands hold vast stocks of $\mathrm{C}$ in their soils; their conservation is potentially a natural solution for mitigating climate change.

\section{Afforestation and Reforestation}

Planted forest areas have increased from 168 to 278 Mha since 1990 [14]. These plantations account for $7 \%$ of the world's forest area due to massive afforestation programs to achieve $\mathrm{CO}_{2}$ emissions reduction targets (Kyoto Protocol, REDD+) [13]. The Kyoto Protocol allows countries to claim as credit any $\mathrm{C}$ that is sequestered as a result of reforestation and afforestation. $\mathrm{C}$ sequestration in both soil and aboveground biomass is one of the essential benefits of afforestation and reforestation, as is increasing HWP C stocks [25], [71]. However, fast-growing species are the most frequently used species in afforestation, given that they have a high potential for C sequestration [25], [46], [47]. Species composition, genetics (fast-growth species), spacing and initial land use are the main factors affecting CSS in forested land [46], [72•]. Also, the C sink capacity of forest plantations can be maximized by prolonging the rotation length and adopting suitable practices for each species (e.g. spacing, fertilization, MSP and composition) [50], [54], [55].

Some frequently planted species are more vulnerable than others to disturbances. For example, Eucalyptus is a major component of fire-prone or fire-driven ecosystems of its native Australia. Yet, species in this genus are vulnerable to wildfires in the Mediterranean basin and other regions of the world. Moreover, regions where it has been introduced have undergone massive land use change, especially when they are planted as industrial monoculture forest stands [73]. Likewise, balsam fir (Abies balsamea [L.] Miller), white spruce (Picea glauca [Moench] Voss) and black spruce (Picea mariana [Miller] BSP) are vulnerable to a co-evolved insect defoliator, i.e. the spruce budworm (Choristoneura fumiferana [Clemens]) in the boreal forest of eastern North America [74], [75]. For these tree species, their $\mathrm{C}$ sequestration potential and stability of $\mathrm{C}$ stocks during a disturbance event is still a matter for research and debate. In the interim, tree species that are less vulnerable to catastrophic fire, wind damage, insects and drought can be planted or maintained on the landscape [76]. Yet, with genetic control, planted species vulnerability could be reduced. For instance, Dale et al. [76] have noted that tree invasion by phloem-feeding insects, such as bark beetles (e.g. Dendroctonus spp., Scolytus spp.), is controlled in part by the ability of trees to produce oleoresins; indeed, the primary defence of pine trees (Pinus spp.) is oleoresin, which is a mixture of monoterpenes and resin acids that provides a chemical and physical barrier against biotic intrusions [77], [78]. Wildfires are not only followed by bark beetle outbreaks in coniferous forests (e.g. Pinus radiata D. Don, P. pinaster), but insect irruptions can result in their genesis by weakening and killing susceptible individuals, thereby creating a ready source of fuel [79]. Therefore, planting selected tree species and genotypes with relatively high oleoresin contents could limit insect outbreaks. Furthermore, the use of mixed stands may reduce the risk of pest and pathogen outbreaks, compared to monocultures, since there is a negative correlation between tree species diversity and the level of damage [80].

The effects of afforestation and reforestation on SOC are not fully understood. Some researchers have pointed out that afforestation could decrease SOC, whereas others have reported positive effects. For instance, afforestation of pastures with pine plantations leads to decreased SOC [81], but other studies have presented contradictory results [82]. For broadleaf plantations, the results are quite variable [81], [83]. A review of the literature suggests that the effect of afforestation on SOC is generally related to initial land use (e.g. forest land, grassland, cropland) [20••], [84]. From a meta-analysis on data that were obtained from 74 publications, Guo and Gifford [81] determined that soil C declines after land use conversions from pasture to plantation $(-10 \%)$ and native forest to plantation $(-13 \%)$, but it increases after land use changes from cropland to plantation $(+18 \%)$ and cropland to secondary forest $(+53 \%)$. 


\section{Applied Silvicultural Treatments in Extensive and Intensive Forest Management}

This section presents common silvicultural treatments and practices that are applied in EFM and IFM (or both), and which are used to improve forest growth and stand harvested volume after stand establishment. Generally, practices with high operating and investment costs such as pre-commercial thinning (PCT) and pruning (including coniferous brushing and formative shaping of broadleaves) are used in IFM (afforestation) [85]-[88]. PCT also could be used in EFM to improve the uneven-aged stand volume over a long rotation period. Clear-cutting (CC) is globally the most widely used silvicultural treatment that is applied in IFM [89]-[91]. About 50\% and 93\% of all timberlands in temperate and boreal forests respectively involve CC methods [90], [93•], while both CC (mainly in the tropical rainforest) and selective logging have been widely employed to harvest tropical forests [91]. In EFM, $\mathrm{PC}$ and selective cutting treatments are frequently used to promote natural regeneration [93•]. PC ranges from retention silviculture to more selection-oriented treatments that have been adapted to the boreal forest. It generally has been more recently applied to this biome $(<20$ years) [89], despite being used in other biomes for at least a century [91].

\section{Pruning}

Pruning is applied to specific high-value tree species to improve stem quality (reduce knots size and presence) and vigour, together with overall tree growth [85], [86]. Pruning can also increase forest $\mathrm{C}$ sequestration rates. For example, a study by Medhurst et al. [85] on native Australian blackwood (Acacia melanoxylon R.Brown) demonstrated increased photosynthetic capacity between 2 and 6 weeks after pruning, to levels that were as much as $50 \%$ higher than the no-pruning controls, depending upon pruning location (i.e. upper-, middle- or lower-crown). C sequestration was found to be $33 \%$ and $62 \%$ higher in the upper- and middle-crown treatments, respectively, compared to the unpruned treatment [85]. Yet, Pinkard and Beadle [86] have claimed that lower pruning of $50 \%$ of the crown depth had no effect on height or diameter increment, while removal of $70 \%$ of the lower crown depth resulted in severe reductions in both parameters, thereby reducing forest $\mathrm{C}$ sequestration rates. Regarding SOC, pruning has an effect similar to stem-only harvesting [94]. Indeed, when the branches are removed and left in situ, their $\mathrm{C}$ and nutrient contents are transferred to the deadwood pool, increasing SOC in the long term as a direct result of the decomposition process.

\section{Pre-commercial Thinning}

PCT is conducted in the interval between canopy closure and final harvest, removing the smaller-, weaker- and poorerquality stems, and could be applied several times during the rotation period [95], [96]. It is largely applied in even-aged, post-fire stands of black spruce and jack pine (Pinus banksiana Lambert), and to second-growth stands of balsam fir. PCT generally precedes the final cut by $15-20$ years [89], [97]. PCT from below initially redistributes $\mathrm{C}$ among pools, i.e. from the biomass to deadwood, and increases forest $\mathrm{C}$ sequestration capacity as a long-term effect, which mainly is expressed in the biomass [87], [88]. In fact, the application of this method reduces competition for light, water and nutrients, thereby improving tree growth; this positive effect depends upon the intensity and frequency of thinning [95], [98]. Moreover, in a 25-year study by Hoover and Stout [96], thinned-from-below plots (about 35\% basal area removal) had greater volume production and $\mathrm{C}$ sequestration rates than plots where thinning from the middle or above was applied (Supplementary Information). Thinning-from-below as a pre-commercial treatment could increase CSS, because all harvested trees remain on the ground (increasing soil C stocks), while residual trees accumulated $\mathrm{C}$ at a faster rate, depending upon the species [87], [94], [99••], [100]. For instance, Ruano et al. [100] report that 5 years after thinning, the height and the basal area of Aleppo pine (Pinus halepensis Miller) had increased by $20 \%$ compared to control stands. PCT treatments from above or middle have been shown to display negative $\mathrm{C}$ sequestration rates, storing significantly less $\mathrm{C}$ than thinning-from-below or control treatments (no thinning) [96]. Thinning-from-above could increase the decomposition process and ecosystem respiration (C loss), since this treatment exposes deadwood and litter to light and stimulates microbial activity [101]. For instance, Concilio et al. [102] and Campbell et al. [101] report a $43 \%$ increase in soil respiration 2 years following thinning-from-above of a mixed-conifer forest. On the other hand, thinning could stimulate the shrub layer, which can also result in net $\mathrm{C}$ loss and a lower C sequestration rate of the stand [101]. In some circumstances in boreal forests, root grafting could affect the growth response to thinning. For instance, in jack pine boreal forest, root grafting could considerably increase the radial growth of trees after thinning [103].

\section{Harvesting Treatments: Clear-Cuts Versus Partial Cuts}

Like severe wildfires, CC may switch forests from being a sink to a source of $\mathrm{C}$ by increasing respiration and reducing leaf biomass and, therefore, photosynthesis in the period following disturbance (Fig. 3) [30]. Using more than 180 site-years of eddy covariance measurements of $\mathrm{C}$ fluxes that were made on forest chronosequences in North America, 


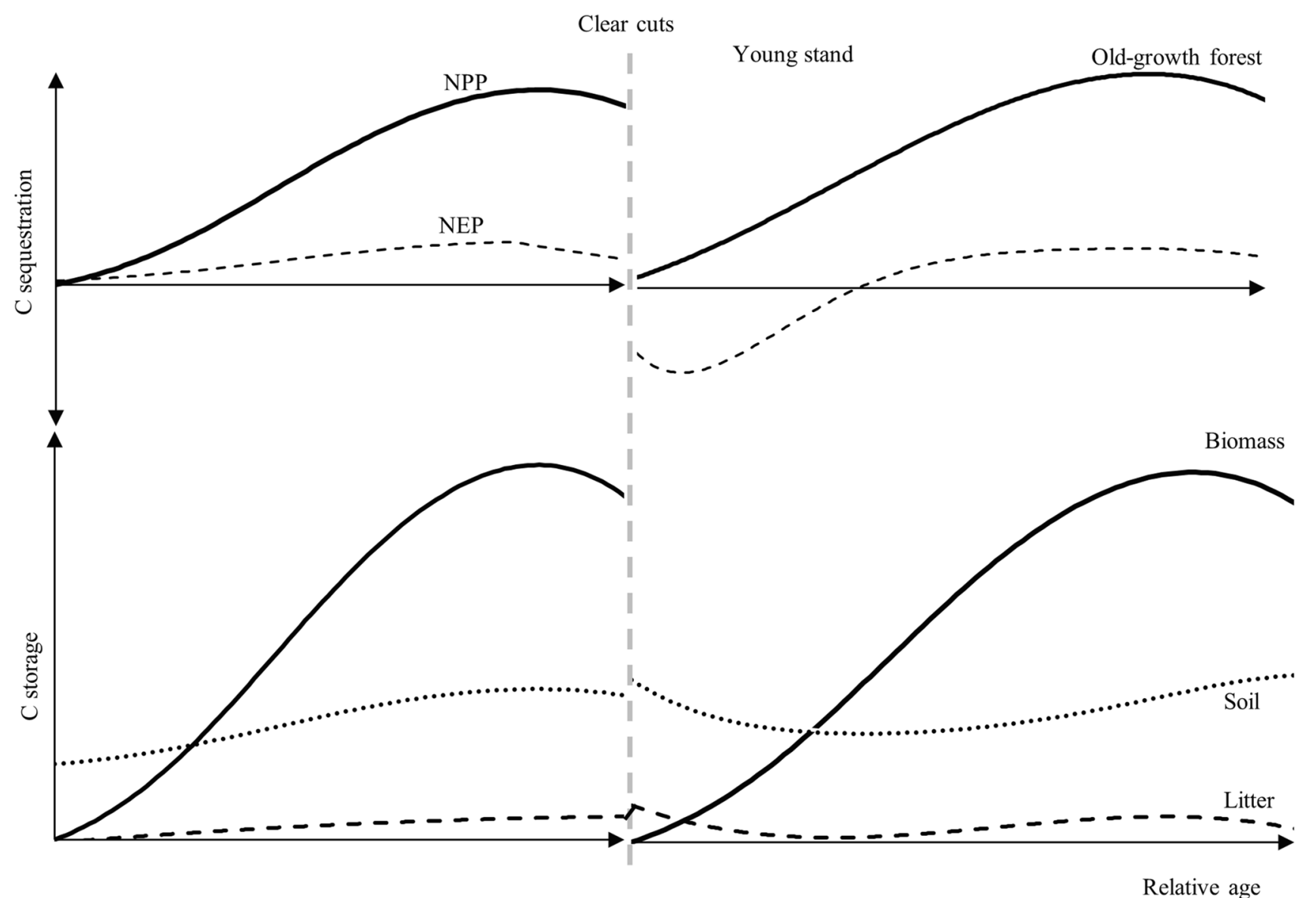

Fig. 3 Theoretical C stock and flux changes of a forest ecosystem following a stand-replacing disturbance event (clear-cut), [18][30] adapted from Goulden et al. and Liu et al. with the changes in net primary productivity (NPP) and net ecosystem productivity (NEP)

Amiro et al. [104] found that NEP exhibited C losses from all ecosystems following a stand-replacing disturbance. Postdisturbance $\mathrm{C}$ balances after $\mathrm{CC}$ depend upon many ecosystem processes, including regeneration and vegetation succession, photosynthesis and respiration [18]. Canopy removal that is associated with CC can increase the amounts of solar radiation and precipitation that reach the soil surface, thereby increasing soil temperature and soil moisture, and consequently increasing $R_{\mathrm{h}}$ and reducing NEP [105], [106]. Over time, NPP and biomass accumulation increase in the youngest stands, and inputs of new litter cause the detrital pools to build up, resulting in an extended period of $\mathrm{C}$ accumulation and a positive NEP. In the oldest stands, mortality and decomposition losses accelerate, which causes NEP to approach zero (Fig. 3) [18], [30]. Overall, the ecosystem attains net $\mathrm{C}$ gain after about 20 years following $\mathrm{CC}$, due to forest regrowth [107]. CC exports close to $100 \%$ of the aboveground biomass pool as HWP and transfers the rest in the deadwood pool as harvest residues, thereby reducing NEP and altering the ecosystem NPP of the replacement stand [18], [30].
$\mathrm{PC}$ are thus gaining interest as alternatives to $\mathrm{CC}$ in the face of climate change, since they could enhance forest $\mathrm{C}$ sequestration, with possibly lower impacts on SOC [23], [58]. Bose et al. [89] defined PC as "a generic term, which refers to a whole range of treatments from clearcutting with sparse, dispersed retention in which a few merchantable stems are left on site, to single-tree selection systems where the very evidence of a harvesting treatment might be too subtle to be noticed by an untrained eye". PC includes a broad range of treatments, such as shelterwood cutting, selection (distant or close), retention systems and seed-tree systems [89], [108•]. Based upon a simulation model in the Canadian boreal forest focusing on red spruce stands (Picea rubens Sargent), Taylor et al. [109] found that total ecosystem C increased in PC stands throughout the 240-year simulation from 308.9 to $327.3 \mathrm{Mg} \mathrm{ha}^{-1}$, while it decreased in CC stands to $305.8 \mathrm{Mg} \mathrm{ha}^{-1}$. Based upon an ecosystem process model (CENTURY) that ran for 5000 years, Peng et al. [110] determined that PC could increase $\mathrm{C}$ sequestration, by about $36-40 \%$ in the boreal forest region. 
The positive effect of $\mathrm{PC}$ on forest $\mathrm{C}$ sequestration depends upon harvesting intensity. In fact, Lee et al. [92] affirm that annual $\mathrm{C}$ assimilation rates in the post-harvest period (after 5 years) in boreal mixedwood stand were substantially higher in control (uncut forest: $3.1 \mathrm{Mg} \mathrm{ha}^{-1}$ year $^{-1}$ ) than PC with two-thirds of the volume being removed (1.8 $\mathrm{Mg} \mathrm{ha}^{-1}$ year $\left.^{-1}\right)$, or when clear-cut $\left(0.3 \mathrm{Mg} \mathrm{ha}^{-1}\right.$ year $\left.^{-1}\right)$. Most empirical studies, however, have been conducted at the plot scale (e.g. [23], [92], [111], [112]). Furthermore, experimental results from individual studies are highly variable, mainly due to differences in harvest intensity (removed volume) and the number of recovery years after cutting. For example, some studies have documented substantial increases in forest NPP and soil C storage following PC [92], [111], whereas others have shown non-significant effects or decreases in forest CSS [101], [113]. Consequently, the intensity at which PC is conducted is a very important consideration, to maintain this positive effect on residual trees. We must be able to predict long-term changes in forest $\mathrm{C}$ dynamics at regional and global scales under different intensities. For instance, Øyen and Nilsen [114] reported that PC intensity should not exceed $65 \%$ in southeast Norway to maintain forest biomass sustainability and preserve its contributions to $\mathrm{C}$ sequestration.

The success of the PC approach requires consideration of not only its intensity, but also its form. In fact, some forms of PC could increase post-cutting mortality that is incurred by disturbance, particularly windthrow [108•], thereby reducing NEP. It was determined from several studies that post-cutting mortality following PC ranges from 15 to $74 \%$, which is attributable to windthrow [108•], [115]. Previous research has shown that mortality is proportional to harvest intensity $\left(r^{2}=0.3988\right.$ [109]); it was highest for the treatment that had the highest intensity compared to the control and other treatments [108•], [116•]. Mortality rates that are associated with PC depend upon a range of factors: spatial patterns (edge, residual strips and trails), forest fragmentation and harvesting intensity. Montoro Girona et al. [108 $\bullet$ reported that $60 \%$ of residual trees were dead in seed-tree treatments, compared to $30 \%$ for shelterwood cuts. These results showed that experimental uniform shelterwood cuttings with $50 \%$ harvest intensity successfully reduced the proportion of tree loss compared to the seed-tree system that is employed in Québec's boreal forest. Shelterwood and seed-tree harvesting followed by scarification promotes regeneration through the creation of uniform openings in the canopy, while limiting the growth of competing vegetation [93•].

With respect to SOC, CC might reduce total SOC stocks relative to the effects of PC [65••]. Despite this potential difference, harvesting (PC and CC) exerts a more limited effect on SOC than it does on biomass [23], [65••]. After CC, soil $\mathrm{C}$ stocks appeared in many cases to remain relatively constant, with their variation being linked to $\mathrm{C}$ transfer from the litter (Fig. 3) (e.g. leaves, lifted branches after the cut) and to the site conditions (mainly temperature) [18]. The meta-analysis that was conducted by Nave et al. [117] for temperate forests worldwide shows that harvesting generally results in a small reduction $(-8 \%)$ in total soil C stocks, whereas the mineral horizons showed no significant change overall. In other cases though, forest harvesting had a critical effect on SOC. Covington's [107] results described SOC dynamics following forest harvesting in northern hardwood forests (New Hampshire, USA), showing a decline of 50\% within 20 years following harvest. This decrease was attributed to accelerated decomposition and changes in litter inputs after harvest [118] and to changes in depth distribution of plant roots, altered soil water regimes and temperature regimes that accelerate decomposition [30], [87], [107]. SOC responds to the harvesting methods that have been applied: cut-to-length (short-wood), tree length and full tree (Supplementary Information). Cut-to-length and tree length contribute to the build-up of the SOC pool [94], while the full tree method increases ecosystem respiration and decreases total ecosystem and SOC stocks [[110]]. Soil respiration rates increase following harvesting but are substantially higher after full-tree harvest [119]. Johnson and Curtis [58] reported that harvest residues left on site after cut-to-length and tree length treatments increased SOC by $+18 \%$, while full tree harvest caused a decrease $(-6 \%)$ over the long term. Post-harvest SOC dynamics are thus highly variable and depend not only upon silvicultural treatments, but also on a myriad of abiotic and biotic factors (e.g. soil texture and moisture, temperature, precipitation, species, stands). For instance, in three contrasting climatic zones (e.g. cool temperate, warm temperate and subtropical), Sun et al. [120] report that the total SOC of the $0-20-\mathrm{cm}$ soil layer decreased with increasing mean annual temperature. Climate affects forest SOC by shaping both SOC inputs (changing plant productivity) and outputs (affecting soil fauna metabolism) [121].

\section{Rotation Length}

Another factor to consider in FMS at the stand level is rotation length, which is an effective way of managing the forest $\mathrm{C}$ budget [122]. Shorter rotation lengths are used in IFM, while long rotations are favoured in EFM. Rotation length is commonly used to manage timber yield, but it may also affect forest CSS depending upon tree species and management goals [123]. For instance, Scots pine (Pinus sylvestris L.) stands stored the largest total amount of $\mathrm{C}$ when applying the longest rotation length, which has a duration that can extend beyond 300 years [123]. Boisvenue et al. [122] have stated that $\mathrm{C}$ stocks were lowest in even-aged stands with lower rotation length (100 years), while it was higher in high rotation lengths with 400-year fire return intervals. 
Pérez-Cruzado et al. [124] asserted that increasing rotation length from 10 to 20 years for southern blue gum (Eucalyptus globulus Labillardière) in a humid temperate region (Galicia, Spain) could increase the $\mathrm{C}$ sequestration rate from 7.73 to $10.93 \mathrm{Mg} \mathrm{ha}^{-1}$ year $^{-1}$ and mineral soil C from -0.24 $\mathrm{Mg} \mathrm{ha}^{-1}$ year $^{-1}$ (lost) to $0.18 \mathrm{Mg} \mathrm{ha}^{-1}$ year $^{-1}$ (gained). On the one hand, shortening the rotation length generally decreased the $\mathrm{C}$ stock in living biomass, but increased the $\mathrm{C}$ stock of soil, because the production of litter and harvest residues increased [125]. On the other hand, lengthening rotation not only retains more $\mathrm{C}$ by increasing average stem size, but also delays emissions that occur during harvesting [126].

\section{Even-Aged Versus Uneven-Aged System}

Considering industrial purposes and ease of operations, forests are managed conventionally as even-aged systems under IFM [99••]. However, silviculture systems affect forest CSS differently. Even-aged forests sequester and store more $\mathrm{C}$ in biomass than do uneven-aged systems that are used mainly in EFM, but these store more $C$ in soils [126], [127]. For instance, Nilsen and Strand [127] found that long-term timber production in the uneven-aged stand was estimated to be $95 \%$ of the even-aged stand, and the difference in net $\mathrm{C}$ sequestration was $37 \mathrm{Mg} \mathrm{ha}^{-1}$ in 81 years in favour of the even-aged stand. Over 81 years, there was an increase in mineral soil C (21 $\left.\mathrm{Mg} \mathrm{ha}^{-1}\right)$ in an uneven-aged stand compared to an even-aged stand, which was linked mainly to differences in the $\mathrm{O}$ horizon. In fact, the $\mathrm{C}$ content in the humus layer in the uneven-aged stand was $20 \%$ higher compared to that in the even-aged stand [127]. Moreover, based on model simulations, several studies have shown that uneven-aged systems may be the better alternative strategy. This should be taken into consideration when increasing $\mathrm{C}$ storage and sequestration rates over the long term. Indeed, Seidl et al. [128] concluded that a transition to uneven-aged forestry has considerable potential with regard to increasing $\mathrm{C}$ storage in forest ecosystems and achieving multiple management objectives. Taylor et al. [109], through a simulation that compared management effects of $\mathrm{CP}$ and $\mathrm{CC}$ in the Canadian boreal forest, found that total ecosystem $\mathrm{C}$ increased in uneven-aged stands. Similarly, in temperate forests, Nunery and Keeton [129] reported that C sequestration capacity was greater in uneven-aged systems.

Ruiz-Peinado et al. [99••] noted that uneven-aged stands have continuous litter inputs, thereby ensuring permanent soil and watershed protection, whereas in even-aged stands, there will be periods with no soil cover or only partial soil cover, which could lead to C losses. Laiho et al. [130] reported a $48 \%$ higher diameter increment in uneven-sized Norway spruce forests compared to that in even-sized forests over a 15-year period where the uneven-sized forest was treated with selection cuttings and the even-sized forest with thinning from below. Also, in Finnish forest stands, Pukkala et al. [131] found that uneven-aged systems were more profitable than even-aged plantations when other management objectives (timber and C) were considered. Nevertheless, designing silvicultural approaches that aim to establish an uneven-aged stand structure requires a deep understanding of the competition process. Harvesting intensity should also be considered. In fact, high harvesting intensities could decrease NEP and increase C emissions; in contrast, lower intensities could increase CSS in the long term, regardless of stand age structure [132].

\section{Tree Species Compositions: Mixed Versus Pure Forest Stands}

Tree species richness promotes productivity and affects nutrient and light availability [133], [134]. According to the facilitation and niche complementarity theories (Supplementary Information), mixed stands have higher $\mathrm{C}$ sequestration potential than do pure stands [72•]. Several studies have shown that ecosystems with high tree species diversity are more productive and sequester more $\mathrm{C}$ than low-diversity ecosystems [133], [134]. Erskine et al. [135] found that throughout the tropics, plantations with mixtures were more productive than monocultures, leading to a $55 \%$ increase (on average) in mean tree basal area. Litter production, nutrient return and leaf litter decomposition are higher in mixed plantations than in monocultures [136], which can increase the mobilization of nutrients in the soil and increase the productivity of the mixture considerably [137]. In Scots pine (Pinus sylvestris L.) and European beech (Fagus sylvatica L.) plantations, tree volumes $(+12 \%)$, stand density $(+20 \%)$, basal area growth $(+12 \%)$ and stand volume growth $(+8 \%)$ of the species were higher in mixture compared to the weighted mean of neighbouring pure stands [72•]. Tree species richness also could increase soil $\mathrm{C}$ stocks, through alterations to litter quality, nitrogen fixation and rooting patterns [99••]. For instance, Dawud et al. [138] found that mixed forests (combinations of P. sylvestris, Betula pendula Roth, Carpinus betulus L., Quercus robur L. and Picea abies [L.] H. Karst) had higher SOC stocks in samples that were taken from deeper layers of the soil profile $(20 \mathrm{~cm}$ and $40 \mathrm{~cm})$, compared to topsoil $(0-10 \mathrm{~cm})$. Generally, the ratio $\mathrm{C} / \mathrm{N}$ in deeper layers is significantly and positively related to species diversity [138].

Several avenues of research have shown that pure and mixed stands do not differ in terms of the aboveground standing volume that they attain. Examples include Norway spruce (Picea abies) and European beech mixtures in Northern Europe or mixtures of black spruce and trembling aspen (Populus tremuloides Michaux) in Canada [139•], [140]. In the Canadian boreal forest, Légaré et al. [141] reported that 
aspen exerted a positive effect on black spruce productivity, but only when the aspen constituted $<40 \%$ of stand basal area. It seems that increasing NPP in mixedwoods requires a balance between species that are used and their densities, and should consider the spacing and spatial arrangement of the stands [141], [142]. Therefore, it is important to emphasize that the effects of mixtures on productivity vary with stand development stage, stand density and site conditions [72•].

\section{Old-Growth Forest Conservation}

Old-growth and intact forests are critical in stabilizing terrestrial $\mathrm{C}$ storage, maintaining biodiversity and providing other ecosystem functions [17••], [22]. These forests represent $22 \%$ of the world's forested land surface $\left(12 \mathrm{M} \mathrm{km}^{2}\right)$, of which three countries (Russia, Brazil and Canada) account for nearly two-thirds of that area. Furthermore, Canada represents $25 \%$ of the world's remaining primary forest, while tropical South America (including Amazon rain forest) represents $35 \%$, but with a high rate of reduction or loss (7.1\% during 2000-2013), compared to the boreal (0.3\% in North America) and temperate (0.9\% in South America temperate forest) forests $[17 \bullet \bullet]$. However, the extent of the world's intact forests has been reduced by $7.2 \%$ (a reduction of $919,000 \mathrm{~km}^{2}$ ) since 2000 ; the primary global cause of this loss is industrial timber extraction that has resulted in forest landscape alteration and fragmentation [17••], [143].

Old-growth forests alone sequester about $1.36 \mathrm{Pg}_{\text {year }}{ }^{-1}$ of $C[144 \bullet \bullet]$. The older trees (and stands) may exhibit reduced uptake rates, but the $\mathrm{C}$ that is stored in soils and biomass within them can greatly exceed that of younger stands [18], [144••], [145]. McGarvey et al. [146•] found that total $\mathrm{C}$ density is $30 \%$ higher $\left(154 \mathrm{Mg} \mathrm{ha}^{-1}\right)$, and deadwood C density is $1800 \%$ higher $\left(120 \mathrm{Mg} \mathrm{ha}^{-1}\right)$ in old-growth forests than in surrounding younger stands $\left(5 \mathrm{Mg} \mathrm{ha}^{-1}\right)$. Old-growth forests contribute considerably more to increased soil $\mathrm{C}$ from accumulated deadwood than do IFM and EFM [146•]. On the one hand, stand age correlates positively with tree biomass and $\mathrm{C}$ accumulation until an advanced age where net $\mathrm{C}$ uptake is thought to be balanced by respiration and increased mortality [147]. Therefore, older tree cohorts store $\mathrm{C}$ less efficiently in live woody tissues, although they can continue accumulating $C[144 \bullet \bullet]$. On the other hand, numerous studies expect that much of this $\mathrm{C}$ will move back to the atmosphere if these forests are disturbed or replaced with younger forests [148]. Current deforestation emissions are about $1.2 \pm 0.6 \mathrm{Pg}_{\text {year }}{ }^{-1}$ of $\mathrm{C}$, but only $12 \%$ of the global intact forest area is protected [17••], [143]. During the period 2000-2013, the tropical regions are responsible for $60 \%$ of the total reduction of the intact forest; tropical South America lost $322,000 \mathrm{~km}^{2}$, whereas Africa lost 101,000 km². The temperate and southern boreal regions contributed $21 \%$ to the global area loss $[17 \bullet \bullet]$. Consequently, the old-growth conservation strategy must be promoted by reducing deforestation and degradation. The latter problems need to be addressed in the short term, especially in the tropics.

\section{Discussion}

$\mathrm{C}$ stocks and fluxes in temperate, tropical and boreal forests are considered to be promising mitigation strategies for addressing climate change. This review aims to better understand the effects of management on $\mathrm{C}$ among forest ecosystems to maximize their potential as mitigation tools. The purposes of forest management could be classified as follows: (a) conservation or restoration of natural areas (e.g. conservation of old-growth forest), (b) EFM where productivity and other services are balanced by maintaining native ecosystems and biological diversity and (c) IFM using plantations (generally as mono-specific, even-aged systems) and intensive silviculture (e.g. mainly planting, MSP, fertilization, CC). Yet, the challenge is to link disturbances regimes (e.g. harvesting, wildfires, windthrow) to the climatic and site conditions, which affect their severity and extent, together with forest regeneration and tree growth.

This review determined the potential for applying different management practices, in terms of their effects on CSS (Table 1). The MSP and fertilization used in IFM are two practices that could increase forest $\mathrm{C}$ sequestration capacity and SOC in the long term. However, MSP could decrease SOC in the short term, so lower-moderate MSP techniques (scarification, mounding or disc trenching) are suggested to reduce these negative effects [63], [64•], [66]. Jandl et al. $[65 \bullet \bullet$ emphasize that the selected technique of MSP is important and will determine whether net $\mathrm{C}$ effects of the activity are positive or negative. MSP methods may lead to multiple interactions among soil physical and chemical properties that influence forest CSS; their long-term impacts on soil $\mathrm{C}$ are still a matter of research, while their positive effects on living biomass are well known. Thinning-frombelow as a pre-commercial treatment could increase forest CSS in IFM and EFM [96], [101], [102]. In commercial treatments, extensive ones (PC, thinning and selective cutting) are highly recommended to increase forest NPP and SOC [23], [65••], [92]. When timber quality is the goal of IFM, upper and middle pruning could be used to promote C sequestration in soil and biomass [85]. Nevertheless, little is known about the effects of management on $\mathrm{C}$ sequestration and storage in soils; work published over the last two decades encourages extensive treatments rather than intensive ones [58], [65••], [114], [118], since SOC reduction is expected under climate change [27]. All practices should be avoided that would accelerate this reduction. 
Table 1 A summary of the expected effects of different practices that are applied in extensive forest management (EFM) and intensive forest management (IFM) on carbon sequestration (NPP) and soil organic carbon (SOC)

\begin{tabular}{|c|c|c|c|c|}
\hline \multirow[t]{2}{*}{ Practices } & \multirow[t]{2}{*}{ FMS } & \multicolumn{3}{|c|}{ Expected effects on CSS } \\
\hline & & NPP & Soil C storage & \\
\hline MSP & IFM & Increase & Decrease $^{\text {a }}$ & \\
\hline Fertilization & IFM & Increase & & \\
\hline \multicolumn{5}{|l|}{ Pre-commercial treatments } \\
\hline Upper and middle pruning & IFM & Increase & & \\
\hline Lower pruning & & Decrease & Increase & \\
\hline Thinning-from-below & Both IFM and EFM & Increase & & \\
\hline Other thinning methods & & Decrease & & \\
\hline \multicolumn{5}{|l|}{ Commercial treatments } \\
\hline $\mathrm{CC}+$ cut-to-length or tree length & IFM $^{b}$ & Decrease & Increase & \\
\hline $\mathrm{CC}+$ full tree & IFM & Decrease & & \\
\hline $\mathrm{PC}<2 / 3+$ full tree & $\mathrm{EFM}^{\mathrm{b}}$ & Increase & Decrease & \\
\hline $\mathrm{PC}<2 / 3+$ cut-to-length or tree length & EFM & Increase & & \\
\hline Long rotation & EFM & Increase & & \\
\hline Short rotation & IFM & Increase & Decrease & \\
\hline Uneven-aged stands & EFM & Increase & & \\
\hline Even-aged stands & IFM & Increase & & Decrease \\
\hline Mixed forest & IFM or EFM & Increase $^{c}$ & & \\
\hline Monoculture & IFM & Increase & Decrease & \\
\hline Old-growth forest conservation & Conservation & Decrease & Increase & \\
\hline
\end{tabular}

$M S P$ mechanical soil preparation, $C C$ clear-cutting, $P C$ partial cuts

${ }^{a}$ MSP effect depends upon the technique that is used and its intensity; it decreases the SOC only in the short term

${ }^{b}$ We assumed that $\mathrm{CC}$ is used only in IFM as final commercial cutting, while PC are used in EFM

${ }^{c}$ Requires balancing among species that are being used. However, $\mathrm{C}$ accumulates in biomass and in the litter layer, which provides slow build-up of the $\mathrm{C}$ pool in the mineral soil
Conservation strategies maintain more $\mathrm{C}$ storage in soils than do EFM and IFM [146•]. EFM increases forest C sequestration capacity in the long term [129], while IFM (e.g. planting + MSP + fertilization) has the highest $\mathrm{C}$ rate capacity in the short and medium terms (Fig. 4) [65••]. EFM compromises between NPP and SOC, both being an intermediate between conservation and IFM (Fig. 4). In EFM, we recommend the application of thinning-from-below in the early stages of stand development [88], [99••]; then, in the final harvest, PC (intensity, as defined by managers must be less than $2 / 3$ of the volume harvested) will maintain both $\mathrm{C}$ sequestration and storage, preferably combined with cut-to-length or tree-length to maintain SOC in the medium and long terms [58], [92], [109]. EFM will eventually replace the biomass that is lost in the harvest in favour of the residual trees, and the pool will equal or exceed its pre-treatment storage if post-cutting mortality is managed [23], [95], [108•]. Following PC, post-cutting mortality could be alleviated by selecting the adequate PC treatment and harvest intensity for each stand (e.g. uniform shelterwood cuttings in boreal forest) [108•]. Yet, extensive treatments increase structural diversity and support uneven-aged systems and natural regeneration, enhancing aboveground
C storage capacity [109], [128]. Indeed, extensive treatments (selection or partial cutting) maintain complex forest structures, which allow for greater light infiltration and promote more efficient resource use by trees [149]. They likewise maintain $\mathrm{C}$ stock stability and reduce vulnerability to natural disturbances, mainly wildfires, by reducing fuels and crown density [76], [150]. With the application of a conservation strategy, maintaining a high stand density (old-growth forest) would maximize the soil C pool [65••], [144••]. Consequently, encouraging such a strategy would likely improve the climate change mitigation benefits of forests. In the Canadian boreal forest, a conservation strategy that aims to maintain $50 \%$ of old-growth forests could then have a positive impact on the $\mathrm{C}$ budget, mainly in soil pools.

Forest soils are considered to be a potential C sink. Post and Kwon [151] reported that the average rate of soil $\mathrm{C}$ sequestration was 0.3 tonnes $\mathrm{ha}^{-1}$ year $^{-1}$ (range: 0-3 t $\mathrm{ha}^{-1}$ year $^{-1}$ ) across different climatic zones. Furthermore, soils store $68 \%$ of the world's forest C (32\% in vegetation) considering only soil and vegetation pools (see Fig. 2), and $44 \%$ when considering all pools [2•]. Consequently, strategies that increase soil $\mathrm{C}$ sequestration and storage should be promoted. $\mathrm{C}$ inputs to the soil come from roots, dead trees 


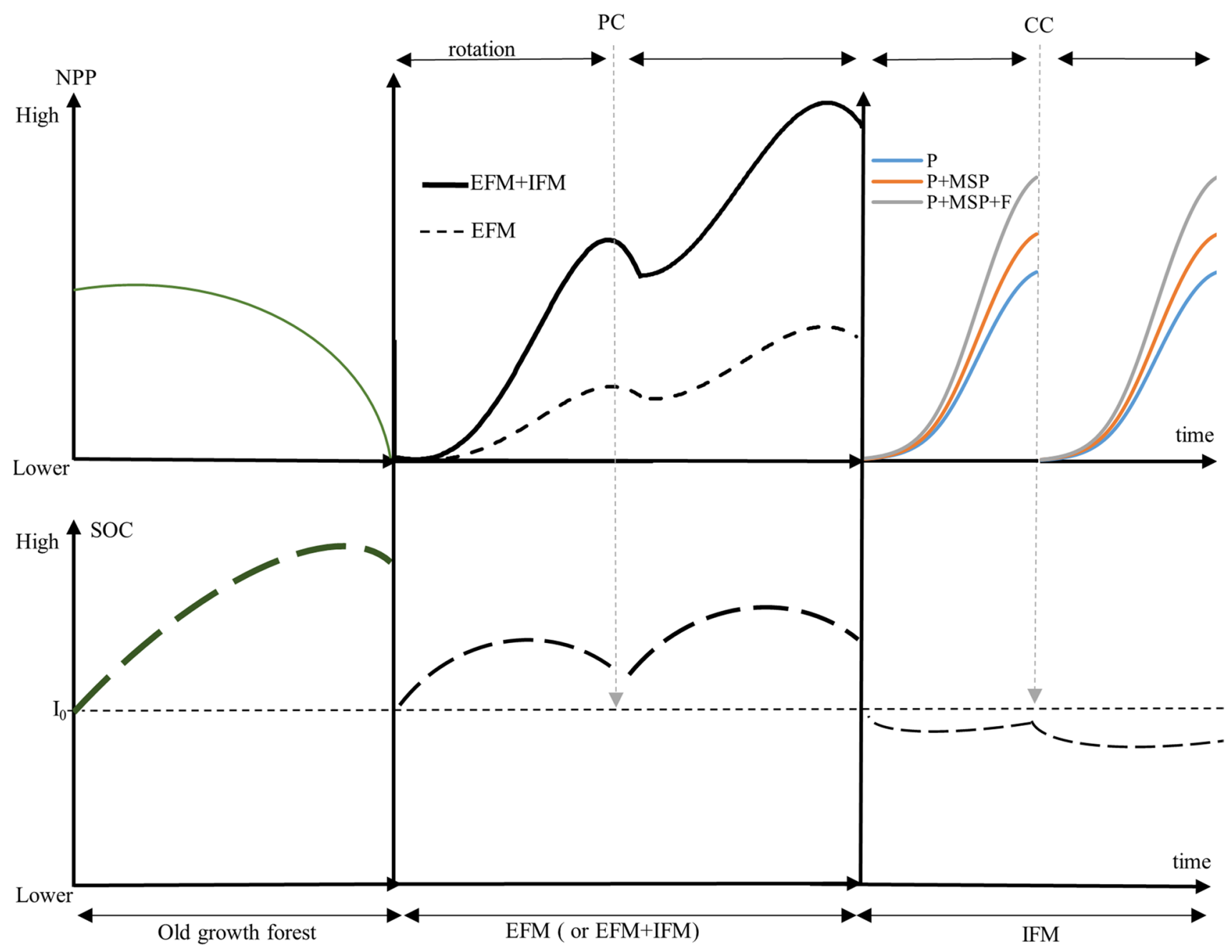

Fig. 4 The theoretical pattern of carbon sequestration capacity and soil carbon storage (SOC) in three systems, where we assumed that SOC starts with an initial stock value $I_{0}$ : intensive forest management (IFM), extensive forest management (EFM) and old-growth forest conservation strategies. EFM strategy compromises carbon sequestration and carbon storage, both being intermediate between the conservation and IFM strategies (legend: $\mathrm{P}$, plantation; F, fertilization; and

and litterfall and are lost through $R_{\mathrm{h}}[34 \bullet]$. Soil C storage is generally sustained by a continuous input of organic matter, meaning that the conservation strategy of old-growth forests could increase this pool [144••], [146•]. Regarding extensive or intensive treatments (PC vs. CC), several studies found conflicting results; some research indicated that harvest decreases soil C sinks, whereas others reported positive effects. Indeed, it has been suggested that harvesting reduces soil C [117], but others showed an increase [152], and some studies found no effect [18], [23], [30], [58]. In a meta-analysis of 112 publications from around the world, harvesting reduced soil $\mathrm{C}$ stocks by an average of $11.2 \%$, with the greatest losses being occurred in organic horizons $(-30.2 \%)$, lower losses occurring in the uppermost mineral
MSP: mechanical soil preparation). This figure also shows the theoretical effects of clear-cuts (CC) and partial cuts (PC) on forest carbon sequestration and storage during a rotation period; we have assumed that post-mortality is managed in EFM by using an adequate PC form and intensity (for details, see text in the section "Harvesting Treatments: Clear-Cuts Versus Partial Cuts")

soil (0-15 cm depth; $-3.3 \%)$ and significant losses in deep soil layers $(60-100+\mathrm{cm} ;-17.7 \%)[20 \bullet \bullet]$. However, this variation is likely related to differences among studies in terms of harvest intensity, tree composition, stand ages and the length of time following harvest [152-154]. Rannik et al. [154] and Strukelj et al. [155] found that 5 to 9 years after $\mathrm{CC}$, the soil pool remained a significant $\mathrm{C}$ source. In selective cuts, Pötzelsberger and Hasenauer [152] found that soil $\mathrm{C}$ was a significant $\mathrm{C}$ sink, increasing by $11 \%$.

Assessment of the forest sector's contribution to climate change mitigation must be at the sector level, and not only within the ecosystem, which means that HWP contributions must be considered. The HWP pool stores the $\mathrm{C}$ beyond the ecosystem and participates in reducing greenhouse 
gas (GHG) emissions through its long-term storage of C, which depends upon its uses and life cycle (Figs. 1, 2) [19]. An additional benefit occurs by substituting materials that generate more greenhouse gases through their production with HWP or by substituting fossil fuel energy with renewable sources, such as biomass energy [19]. Yet, the global demand for industrial wood is expected to double over 2030-2050 [156]; consequently, harvesting pressures on world forests will increase significantly. According to our review, an EFM strategy is a promising approach to fulfill this demand, particularly if it is combined with some IFM practices (MSP and fertilization) in localized areas (Table 2, Fig. 4). In fact, combining IFM and EFM practices result in an increase in landscape productivity and soil $\mathrm{C}$ storage in both the short and long terms compared to IFM (Fig. 4).

An adaptive FMS to maximize CSS at the landscape scale is important since it is considered a political concern; forests are not managed on a single stand basis, but at the landscape scale [94], [95], [157]. Indeed, landscape-scale $\mathrm{C}$ stock changes are the sum of stand-level changes, and the effects of forest management on $\mathrm{C}$ stocks ultimately must be evaluated at the landscape scale [157]. Therefore, managers could diversify FMS at the landscape scale, given that this approach could increase CSS and harvested volumes. This approach was developed by Seymour and Hunter [158] and denoted "functional zoning" (TRIAD approach). It has been used in parts of boreal Canada as a potential strategy for achieving diverse objectives by dividing the landscape into three zones: conservation zone, IFM zone and EFM zone. The IFM zone is characterized by high-input, production-focused plantation silviculture. The EFM zone, where less-intensive approaches such as ecological silviculture are used, allows non-timber objectives (e.g. biodiversity conservation, aesthetics) to be met, while providing an opportunity for timber production [159]. The conservation zone represents the unmanaged forest and ecological reserves. The establishment of the TRIAD strategy requires a forest management approach that integrates several spatial and temporal scales, and all zones need to be managed in an integrated fashion to ensure sustainable management [160]. The challenge lies in determining the appropriate proportion for each zone, as large proportions are not recommended for IFM, for instance. The IFM zone could mostly use the productive areas (high site indices). Irland [7•] states that IFM is likely to be attractive to landowners on such sites, and maybe financially unwarranted on the ones with the lowest productivity. Therefore, the TRIAD approach could be guided by the site index and cost-effectiveness. However, at the stand scale, the effects of all the practices that are discussed on forest CSS are very sensitive to site conditions and the climate [161].

The question that is raised by this review relates to the economic feasibility of the proposed practices to be implemented in IFM and EFM. MSP, fertilization, pruning and thinning-from-below have additional costs. In order to harvest the same volume using PC as with CC, PC must be applied in different places and requires greater access to the forest (operational barriers), compared to $\mathrm{CC}$, thereby making PC more costly. Mixed stands favour $\mathrm{C}$ sequestration, but maintaining the balance among the mixed species may be difficult and could be more expensive than monoculture [162]. Nichols et al. [162] assume that the prices and scheduling of silvicultural and harvesting operations remain unchanged between monoculture and mixed stands, but establishment costs could be higher in mixed stands. Yet, these practices improve productivity (more harvested volume). Therefore, they generate more revenue in the long term, but require higher initial investments. IFM is always used because it is more profitable than EFM. We still need to integrate externalities and $\mathrm{C}$ offset measures to compare the profits between EFM, IFM and conservation [163].

Table 2 The main broad contrasts between the ends of the spectrum of IFM and EFM strategies, and their expected effects on carbon sequestration, with the possibility of mixing both strategies at the landscape scale

\begin{tabular}{llll}
\hline & IFM & EFM & IFM + EFM \\
\hline Stand establishment & MSP & - & MSP \\
& Fertilization & - & Fertilization \\
Rotations & Shorter & Longer & Longer \\
Stand composition & Single species & Mixtures & Mixtures \\
Structure & Even aged & Uneven-aged & Uneven-aged \\
Pre-commercial treatments & Thinning & Thinning & Thinning \\
Commercial treatments & Clear-cuts & Partial cuts or selective & Partial cuts or selective \\
Carbon sequestration in the short term & High & Modest to low & High \\
Carbon sequestration in the long term & Modest to low & High & High \\
\hline
\end{tabular}




\section{Conclusion}

After reviewing several practices that are applied in EFM and IFM, we can conclude that increasing forest $C$ sequestration capacity requires an understanding of the effects of management, climate and industry, together with predictions as to how these effects might change in forest ecosystems over time (long and short terms). Silvicultural practices and systems could be used to convert existing stands to more suitable stand structures and compositions, which may increase $\mathrm{C}$ sequestration as well as mitigate and adapt ecosystems to the effects of global change. PC with cut-to-length or tree-length harvesting systems has been identified as one of the major solutions for increasing biomass and soil $\mathrm{C}$ content. Yet, their long-term effects are not fully understood, mainly when we consider the form and intensity of PC, which requires further research on this topic. Regarding global strategies, each one has its advantages: conservation increases SOC storage, IFM increases $\mathrm{C}$ sequestration capacity in biomass in the short term and EFM is a compromise between conservation and IFM and is more effective in the long term. Consequently, the diversification of those strategies at the landscape scale under the TRIAD zonation approach could be the best direction for increasing forest $\mathrm{C}$ sequestration capacity, instead of using only one strategy. On the one hand, the applied proportion of each strategy should depend upon the managed territory as well. On the other hand, natural disturbance regimes and climate change could greatly enhance or reduce $\mathrm{C}$ storage capacity and should be considered in subsequent management decisions.

We highlight that all of the practices and strategies that have been discussed in this review are applied in almost all biomes. Moreover, their effects are similar, although the magnitude of these effects differs, mainly in terms of the practices that accelerate $R_{\mathrm{h}}$. For example, in the boreal forest, CC will increase $R_{\mathrm{h}}$ and reduce $\mathrm{SOC}$, but not to the same magnitude as seen in tropical and temperate forests, where the climate is warm. The warmer climate will substantially increase ecosystem $R_{\mathrm{h}}$ following CC and, therefore, will induce very substantial reductions in SOC compared to the boreal biome. Many knowledge gaps remain, however, given that the long-term effects of these practices on forest $\mathrm{C}$ budgets in each biome at regional and global scales are still poorly understood, especially when considering how a changing climate might alter these effects. This review does not aspire to cover all aspects of management and their effects on forest $\mathrm{C}$, nor does it discusses all relevant implications. Instead, it provides forest managers with an overview of promising practices and strategies that can be implemented to mitigate climate change, by increasing forest $\mathrm{C}$ sequestration capacity.
Supplementary Information The online version contains supplementary material available at https://doi.org/10.1007/s40725-021-00151-w.

Acknowledgments This work was made possible by the funding from DESI (Développement économique Sept-Îles), Quebec Ministry of Forests, Wildlife and Parks (MFFP) and Natural Sciences and Engineering Research Council of Canada (NSERC). We thank W.F.J. Parsons for English language revision and E. Imbeau for the fantastic visual design improvements made in Fig. 1. Also, we thank the referees and editors for their extremely valuable comments and suggestions on the manuscript.

Author Contribution The manuscript was written by the first author as part of his PhD program at UQAT (Université du Québec en AbitibiTémiscamingue) under the supervision of Yves Bergeron and Xavier Cavard. Osvaldo Valeria and Miguel Montoro Girona (UQAT) were invited to be co-authors to improve the manuscript. All co-authors read, commented and approved the final manuscript. YB and XC funded the project. All authors have read and agreed upon the submitted version of the manuscript.

Funding Open access funding was provided by "Chaire de Recherche UQAT-MFFP sur la gestion du carbone forestier".

\section{Declarations}

Conflict of Interest The authors declare that the research was conducted in the absence of any commercial or financial relationships that could be construed as potential conflicts of interest.

Human and Animal Rights This article does not contain any studies with human or animal subjects that were performed by any of the authors.

Open Access This article is licensed under a Creative Commons Attribution 4.0 International License, which permits use, sharing, adaptation, distribution and reproduction in any medium or format, as long as you give appropriate credit to the original author(s) and the source, provide a link to the Creative Commons licence, and indicate if changes were made. The images or other third party material in this article are included in the article's Creative Commons licence, unless indicated otherwise in a credit line to the material. If material is not included in the article's Creative Commons licence and your intended use is not permitted by statutory regulation or exceeds the permitted use, you will need to obtain permission directly from the copyright holder. To view a copy of this licence, visit http://creativecommons.org/licenses/by/4.0/.

\section{References}

Papers of particular interest, published recently, have been highlighted as:

- Of importance

$\bullet$ Of major importance

1. Nelson E, Mendoza G, Regetz J, et al. Modeling multiple ecosystem services, biodiversity conservation, commodity production, and tradeoffs at landscape scales. Front Ecol Environ. 2009;7(1):4-11. https://doi.org/10.1890/080023.

2. -Pan Y, Birdsey RA, Fang J, et al. A large and persistent carbon sink in the world's forests. Science. 
2011;333(6045):988LP-993LP This paper provides relevant information about carbon sinks worldwide, based on forest inventory data and long-term ecosystem carbon studies.

3. Boyd PW, Claustre H, Levy M, Siegel DA, Weber T. Multifaceted particle pumps drive carbon sequestration in the ocean. Nature. 2019;568(7752):327-35. https://doi.org/10.1038/ s41586-019-1098-2.

4. Batjes NH. Total carbon and nitrogen in the soils of the world. Eur J Soil Sci. 1996;47(2):151-63. https://doi.org/10.1111/j. 1365-2389.1996.tb01386.x.

5. Köhl M, Lasco R, Cifuentes M, et al. Changes in forest production, biomass and carbon: results from the 2015 UN FAO Global Forest Resource Assessment. For Ecol Manag. 2015;352:21-34. https://doi.org/10.1016/j.foreco.2015.05.036.

6. Bellassen V, Luyssaert S. Carbon sequestration: managing forests in uncertain times. Nature. 2014;506(7487):153-5.

7. Irland LC. Timber productivity research gaps for extensive forest management. Small-Scale For. 2011;10(4):389-400 This paper offers an extended definition of intensive and extensive management and then discusses general research needs in regeneration, pest management, stand management guides, financial analysis, non-timber values and effects on ecosystem services.

8. Ford-Robertson FC. Terminology of forest science, technology, practice, and products; English-language version. Washington, D.C: Society of American Foresters; 1983. p. 370.

9. Tong X, Brandt M, Yue Y, et al. Forest management in southern China generates short-term extensive carbon sequestration. Nat Commun. 2020;11(1):129. https://doi.org/10.1038/ s41467-019-13798-8.

10. Bergeron Y, Harvey B, Leduc A, Gauthier S. Forest management guidelines based on natural disturbance dynamics: standand forest-level considerations. For Chron. 1999;75(1):49-54.

11. Bongaarts J. Human population growth and the demographic transition. Philos Trans R Soc B Biol Sci. 2009;364(1532):298590. https://doi.org/10.1098/rstb.2009.0137.

12. Foley JA, DeFries R, Asner GP, Barford C, Bonan G, Carpenter SR, et al. Global consequences of land use. Science. 2005;309(5734):570LP-574LP. https://doi.org/10.1126/scien ce. 1111772 .

13. Keenan RJ, Reams GA, Achard F, de Freitas JV, Grainger A, Lindquist E. Dynamics global forest area: results from the FAO Global Forest Resources Assessment 2015. For Ecol Manag. 2015;352:9-20. https://doi.org/10.1016/j.foreco.2015.06.014.

14. FAO. The state of the world's forests 2020. FAO and UNEP. 2020. https://www.fao.org/3/ca8642en/ca8642en.pdf.

15. $\bullet$ Ontl TA, Janowiak MK, Swanston CW, et al. Forest management for carbon sequestration and climate adaptation. J For. 2019;118(1):86-101. https://doi.org/10.1093/jofore/fvz062 This paper provides forest carbon management guidance and could help forest managers to reduce risk from expected climate impacts, and identifies practices for managing forest carbon into the future calls for a recognition of the influences of a changing climate on forest ecosystems.

16. $\bullet$ Noormets A, Epron D, Domec JC, McNulty SG, Fox T, Sun G, King JS. Effects of forest management on productivity and carbon sequestration: a review and hypothesis. For Ecol Manag. 2015;355:124-40. https://doi.org/10.1016/j.foreco.2015.05. 019This paper is an interesting review and is related to our work, it assesses available data on the structure and function of the world's forests, explores the main differences in the $\mathrm{C}$ exchange between managed and unmanaged stands and explores potential physiological mechanisms behind both observed and expected changes.

17. $\bullet P o t a p o v ~ P$, Matthew HC, Lars L, et al. The last frontiers of wilderness: tracking loss of intact forest landscapes from 2000 to 2013. Science Advances. 2017;3(1):e1600821 This paper is one of the rare studies that assess intact and old-growth forests worldwide, and its results illustrate the need for planning and investment in carbon sequestration and biodiversity conservation efforts that target the most valuable remaining forests.

18. Goulden ML, Mcmillan AMS, Winston AV, et al. Patterns of NPP, GPP, respiration, and NEP during boreal forest succession. Glob Change Biol. 2011;17(2):855-71.

19. Smyth CE, Stinson G, Neilson E, et al. Quantifying the biophysical climate change mitigation potential of Canada's forest sector. Biogeosciences. 2014;11(13):3515-29.

20. $\bullet$ Mayer M, Prescott CE, Abker WEA, et al. Tamm review: influence of forest management activities on soil organic carbon stocks: a knowledge synthesis. For Ecol Manag. 2020;466: 118127. https://doi.org/10.1016/j.foreco.2020.118127 This Tamm review is an interesting paper and is very much related to our work. It synthesizes current evidence regarding the influences of 13 common forest management practices on forest soil C stocks.

21. Kurz WA, Shaw CH, Boisvenue C, et al. Carbon in Canada's boreal forest - a synthesis. Environ Rev. 2013;21(4):260-92. https://doi.org/10.1139/er-2013-0041.

22. Harper K, Boudreault C, DeGrandpré L, Drapeau P, Gauthier S, Bergeron Y. Structure, composition, and diversity of oldgrowth black spruce boreal forest of the Clay Belt region in Quebec and Ontario. Environ Rev. 2003;11(S1):S79-98.

23. Zhou D, Zhao SQ, Liu S, Oeding J. A meta-analysis on the impacts of partial cutting on forest structure and carbon storage. Biogeosciences. 2013;10(6):3691.

24. Dixon R. Silvicultural options to conserve and sequester carbon in forest systems: preliminary economic assessment. Crit Rev Environ Sci Technol. 2009;27(sup001):139-49. https:// doi.org/10.1080/10643389709388515 This paper demonstrates that from 40-nation assessment of silvicultural practices and techniques, it was revealed that forest silvicultural practices can contribute to future $\mathrm{C}$ sequestration and mitigate climate change.

25. Nghiem N. Optimal rotation age for carbon sequestration and biodiversity conservation in Vietnam. For Policy Econ. 2014;38:56-64.

26. Neale DB, Kremer A. Forest tree genomics: growing resources and applications. Nat Rev Genet. 2011;12(2):111-22. https:// doi.org/10.1038/nrg2931.

27. Reyer C, Lasch-Born P, Suckow F, Gutsch M, Murawski A, Pilz T. Projections of regional changes in forest net primary productivity for different tree species in Europe driven by climate change and carbon dioxide. Ann For Sci. 2014;71(2):211-25. https://doi.org/10.1007/s13595-013-0306-8.

28. Tian H, Chaoqun L, Yang J, et al. Global patterns and controls of soil organic carbon dynamics as simulated by multiple terrestrial biosphere models: current status and future directions. Glob Biogeochem Cycles. 2015;29(6):775-92. https://doi.org/ 10.1002/2014GB005021.

29. Gower ST. Patterns and mechanisms of the forest carbon cycle. Ann Rev Environ Resour. 2003;28(1):169-204.

30. Liu S, Bond-Lamberty B, Hicke JA, et al. Simulating the impacts of disturbances on forest carbon cycling in North America: processes, data, models, and challenges. J Geophys Res Biogeosci. 2011;116(G4). https://doi.org/10.1029/2010J G001585.

31. Liu Z, Kimball JS, Parazoo NC, et al. Increased high-latitude photosynthetic carbon gain offset by respiration carbon loss during an anomalous warm winter to spring transition. Glob Change Biol. 2020;26(2):682-96. https://doi.org/10.1111/gcb. 14863.

32. Peng C, Apps MJ. Simulating global soil- $\mathrm{CO}_{2}$ flux and its response to climate change. J Environ Sci. 2000;12(3):257-65. 
33. Zeng N, King AW, Zaitchik B, et al. Carbon sequestration via wood harvest and storage: an assessment of its harvest potential. Clim Change. 2012 118. https://doi.org/10.1007/ s10584-012-0624-0

34. •Dixon RK, Solomon AM, Brown S, Houghton RA, Trexier MC, Wisniewski J. Carbon pools and flux of global forest ecosystems. Science. 1994;263(5144):185-90. https://doi.org/10.1126/scien ce.263.5144.185 This paper provides relevant information about carbon storage and sinks worldwide.

35. •-Luyssaert S, Inglima I, Jung M, et al. CO2 balance of boreal, temperate, and tropical forests derived from a global database. Glob Change Biol. 2007;13(12):2509-37 This study offers information on temperate, boreal and tropical forests' carbon sequestration capacity, based on the assessment of ecosystem's NPP and respiration.

36. Deluca TH, Boisvenue C. Boreal forest soil carbon: distribution, function and modelling. Forestry. 2012;85(2):161-84. https://doi.org/10.1093/forestry/cps003.

37. Walthert L, Meier ES. Tree species distribution in temperate forests is more influenced by soil than by climate. Ecol Evol. 2017;7(22):9473-84. https://doi.org/10.1002/ece3.3436.

38. Slik JF, Arroyo-Rodríguez V, Aiba SI, Alvarez-Loayza P, Alves LF, Ashton P, et al. An estimate of the number of tropical tree species. Proc Natl Acad Sci U S A. 2015;112(24):7472-7.

39. Kasischke ES. Boreal ecosystems in the global carbon cycle. In: Kasischke E.S., Stocks B.J. (eds) Fire, climate change, and carbon cycling in the boreal forest. New York, NY: Springer New York. 2000; pp. 19-30. https://doi.org/10.1007/ 978-0-387-21629-4_2.

40. Houghton RA. Tropical deforestation as a source of greenhouse gas emissions. Tropical deforestation and climate change. U.S. Department of Energy Office of Scientific and Technical Information, Brazil. 2005;13. https://www.osti.gov/ etdeweb/biblio/20880378

41. $\bullet$ Malhi Y, Baldocchi DD, Jarvis PG. The carbon balance of tropical, temperate and boreal forests. Plant Cell Environ. 1999;22(6):715-40. https://doi.org/10.1046/j.1365-3040.1999. 00453.x. This is one of the most interesting papers about forest carbon, and it discusses the climatic influences on the carbon dynamics of boreal, temperate and tropical forests by presenting a new synthesis of micrometeorological, ecophysiological and forestry data.

42. -Lavoie M, Paré D, Bergeron Y. Impact of global change and forest management on carbon sequestration in northern forested peatlands. Environ Rev. 2005;13(4):199-240 This paper is a review of the effect of management practices (fertilization, soil mechanical preparation) on carbon sequestration in peatlands.

43. Scharlemann JPW, Tanner EVJ, Hiederer R, Kapos V. Global soil carbon: understanding and managing the largest terrestrial carbon pool. Carbon Manag. 2014;5(1):81-91.

44. Tarnocai C, Canadell JG, Schuur EAG, Kuhry P, Mazhitova G, Zimov S. Soil organic carbon pools in the northern circumpolar permafrost region. Glob Biogeochem Cycles. 2009 23(2) https:// doi.org/10.1029/2008GB003327.

45. ••Magnan G, Garneau M, Le Stum-Boivin É, Grondin P, and Bergeron Y. Long-term carbon sequestration in boreal forested peatlands in Eastern Canada. Ecosystems. 2020 23(7) https://doi. org/10.1007/s10021-020-00483-x. This is a recent study, which highlights the importance of boreal forested peatlands as $\mathrm{C}$ reservoirs and helps in understanding how fires, logging and climate change affect $\mathrm{C}$ sequestration function.

46. Perry DA. The scientific basis of forestry. Ann Rev Ecol Syst. 1998;29(1):435-66.
47. Chappell HN, Weetman GF, Miller RE. Forest fertilization: sustaining and improving nutrition and growth of western forests. Seattle, WA: University of Washington; 1992.

48. DesRochers A, van den Driessche R, Thomas BR. NPK fertilization at planting of three hybrid poplar clones in the boreal region of Alberta. For Ecol Manag. 2006;232(1):216-25. https://doi. org/10.1016/j.foreco.2006.06.004.

49. Elferjani R, DesRochers A, Tremblay F. Effects of mixing clones on hybrid poplar productivity, photosynthesis and root development in northeastern Canadian plantations. For Ecol Manag. 2014;327:157-66. https://doi.org/10.1016/j.foreco.2014.05.013.

50. Sahoo G, Wani AM. Forest biotechnology: current trends and future prospects. Int J Curr Microbiol Appl Sci. 2020;11:74-85.

51. Mathews JH, Campbell MM. The advantages and disadvantages of the application of genetic engineering to forest trees: a discussion. Forestry. 2000;73(4):371-80. https://doi.org/10.1093/fores try/73.4.371.

52. Harrington RA, Fownes JH, Vitousek PM. Production and resource use efficiencies in $\mathrm{N}$-and $\mathrm{P}$-limited tropical forests: a comparison of responses to long-term fertilization. Ecosystems. 2001;4(7):646-57.

53. Pukkala T. Optimal nitrogen fertilization of boreal conifer forest. For Ecosyst. 2017;4(1):1-10.

54. Pregitzer KS, Burton AJ, Zak DR, Talhelm AF. Simulated chronic nitrogen deposition increases carbon storage in northern temperate forests. Global Change Biology. 2008;14(1):142-53.

55. Lal R. Forest soils and carbon sequestration. For Ecol Manag. 2005;220(1-3):242-58.

56. Jassal RS, Andrew BT, Baozhang $\mathrm{C}$, et al. $\mathrm{N}_{2} \mathrm{O}$ emissions and carbon sequestration in a nitrogen-fertilized Douglas fir stand. Journal of Geophysical Research: Biogeosciences. 2008 113(G4) https://doi.org/10.1029/2008JG000764.

57. Berg B, Matzner E. Effect of $\mathrm{N}$ deposition on decomposition of plant litter and soil organic matter in forest systems. Environ Rev. 1997;5(1):1-25.

58. Johnson DW, Curtis PS. Effects of forest management on soil $\mathrm{C}$ and $\mathrm{N}$ storage: meta analysis. For Ecol Manag. 2001;140(2-3):227-38.

59. Bobbink R, et al. Global assessment of nitrogen deposition effects on terrestrial plant diversity: a synthesis. Ecol Applic. 2010;20(1):30-59. https://doi.org/10.1890/08-1140.1.

60. De Vries W, Posch M. Modelling the impact of nitrogen deposition, climate change and nutrient limitations on tree carbon sequestration in Europe for the period 1900-2050. Environ Pollut. 2011;159(10):2289-99.

61. Gundale MJ, Deluca TH, Nordin A. Bryophytes attenuate anthropogenic nitrogen inputs in boreal forests. Glob Change Biol. 2011;17(8):2743-53. https://doi.org/10.1111/j.1365-2486. 2011.02407.x.

62. Smethurst P. Forest fertilization: trends in knowledge and practice compared to agriculture. Plant Soil. 2010;335:83-100. https://doi.org/10.1007/s11104-010-0316-3.

63. Nordborg F, Nilsson U, Gemmel P, Örlander G. Carbon and nitrogen stocks in soil, trees and field vegetation in conifer plantations 10 years after deep soil cultivation and patch scarification. Scan J For Res. 2006;21(5):356-63.

64. •Löf M, Dey DC, Navarro RM, Jacobs DF. Mechanical site preparation for forest restoration. New For. 2012;43(5-6):825-48 This paper synthesizes the current state of knowledge concerning mechanical site preparation for improved tree establishment and growth.

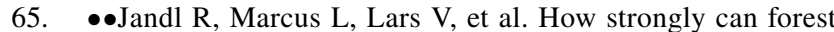
management influence soil carbon sequestration? Geoderma. 2007;137(3):253-68. https://doi.org/10.1016/j.geoderma.2006. 09.003 This paper reviewed the experimental evidence for longterm $\mathrm{C}$ sequestration in soils as a consequence of specific forest 
management strategies. Also, it focused on factors that affect the $\mathrm{C}$ input to the soil and the $\mathrm{C}$ release via decomposition of soil organic matter.

66. Jiménez Esquilín AE, Stromberger ME, Shepperd WD. Soil scarification and wildfire interactions and effects on microbial communities and carbon. Soil Sci Soc Am J. 2008;72(1):111-8.

67. $\bullet$ Mjöfors K, Strömgren M, Nohrstedt H-Ö, Johansson M-B, Gärdenäs AI. Indications that site preparation increases forest ecosystem carbon stocks in the long term. Scand J For Res. 2017;32(8):717-25 This paper assesses for 25 years the effects of mechanical site preparation (disc trenching, mounding and ploughing) on ecosystem $\mathrm{C}$ stocks, $\mathrm{C}$ stocks in soil, ground vegetation and trees.

68. Örlander G, Egnell G, Albrektson A. Long-term effects of site preparation on growth in Scots pine. For Ecol Manag. 1996;86(1-3):27-37.

69. Ross SM, Malcolm DC. Effects of intensive forestry ploughing practices on an upland heath soil in south east Scotland. Forestry. 1982;55(2):155-71.

70. Cui J, Li C, Trettin C. Modeling biogeochemistry and forest management practices for assessing GHGs mitigation strategies in forested wetlands. Environ Model Assess. 2005;10(1):43-53. https://doi.org/10.1007/s10666-004-7261-6.

71. Silver W, Ostertag R, Lugo A. The potential for carbon sequestration through reforestation of abandoned tropical agricultural and pasture lands. Restor Ecol. 2000;8:394-407. https://doi.org/ 10.1046/j.1526-100x.2000.80054.x.

72. •Pretzsch H, del Río M, Ammer C, et al. Growth and yield of mixed versus pure stands of Scots pine (Pinus sylvestris L.) and European beech (Fagus sylvatica L.) analysed along a productivity gradient through Europe. Eur J For Res. 2015;134(5):927-47. https://doi.org/10.1007/s10342-015-0900-4 This study investigates the growth of Scots pine (Pinus sylvestris L.) and European beech (Fagus sylvatica L.) in mixed versus pure stands on 32 triplets located along a productivity gradient through Europe. It identifies the difference of stand state variables, such as mean tree height or mean tree diameter between those species.

73. Doerr SH, Santín C. Global trends in wildfire and its impacts: perceptions versus realities in a changing world. Philos Trans $\mathrm{R}$ Soc B Biol Sci. 2016;371(1696):20150345.

74. MacLean DA. Impacts of insect outbreaks on tree mortality, productivity, and stand development. Can Entomol. 2016;148(S1):S138-59. https://doi.org/10.4039/tce.2015.24.

75. Bergeron Y, Leduc A. Relationships between change in fire frequency and mortality due to spruce budworm outbreak in the southeastern Canadian boreal forest. J Veg Sci. 1998;9(4):492500. https://doi.org/10.2307/3237264.

76. Dale VH, Joyce LA, McNulty S, et al. Climate change and forest disturbances: climate change can affect forests by altering the frequency, intensity, duration, and timing of fire, drought, introduced species, insect and pathogen outbreaks, hurricanes, windstorms, ice storms, or landslides. BioScience. 2001;51(9):723-34.

77. Lombardero MJ, Ayres MP. Factors influencing bark beetle outbreaks after forest fires on the Iberian Peninsula. Environ Entomol. 2011;40(5):1007-18. https://doi.org/10.1603/EN110 22.

78. Franceschi VR, Krokene P, Christiansen E, Krekling T. Anatomical and chemical defenses of conifer bark against bark beetles and other pests. New Phytol. 2005;167(2):353-76.

79. Jenkins MJ, Runyon JB, Fettig CJ, Page WG, Bentz BJ. Interactions among the mountain pine beetle, fires, and fuels. For Sci. 2014;60(3):489-501.

80. Jactel H, Brockerhoff EG. Tree diversity reduces herbivory by forest insects. Ecol Lett. 2007;10(9):835-48.
81. Guo LB, Gifford RM. Soil carbon stocks and land use change: a meta analysis. Glob Change Biol. 2002;8(4):345-60. https:// doi.org/10.1046/j.1354-1013.2002.00486.x.

82. Ross DJ, Tate KR, Scott NA, Wilde RH, Rodda NJ, Townsend JA. Afforestation of pastures with Pinus radiata influences soil carbon and nitrogen pools and mineralisation and microbial properties. Soil Res. 2002;40(8):1303-18.

83. Shi J, Cui L. Soil carbon change and its affecting factors following afforestation in China. Landsc Urban Plann. 2010;98(2):7585. https://doi.org/10.1016/j.landurbplan.2010.07.011.

84. Poeplau C, Axel D, Lars V, et al. Temporal dynamics of soil organic carbon after land-use change in the temperate zone carbon response functions as a model approach. Glob Change Biol. 2011;17(7):2415-27. https://doi.org/10.1111/j.1365-2486. 2011.02408.x.

85. Medhurst JL, Pinkard EA, Beadle CL, Worledge D. Photosynthetic capacity increases in Acacia melanoxylon following form pruning in a two-species plantation. For Ecol Manag. 2006;233(2-3):250-9.

86. Pinkard EA, Beadle CL. Effects of green pruning on growth and stem shape of Eucalyptus nitens (Deane and Maiden) Maiden. New For. 1998;15(2):107-26. https://doi.org/10.1023/A:10065 33423884

87. McHenry MT, Wilson BR, Lemon JM, Donnelly DE, Growns IG. Soil and vegetation response to thinning white cypress pine (Callitris glaucophylla) on the North Western Slopes of New South Wales, Australia. Plant Soil. 2006;285(1):245-55. https:// doi.org/10.1007/s11104-006-9011-9.

88. Schaedel MS, Larson AJ, Affleck DLR, Belote RT, Goodburn JM, Page-Dumroese DS. Early forest thinning changes aboveground carbon distribution among pools, but not total amount. For Ecol Manag. 2017;389:187-98.

89. Bose AK, Harvey BD, Brais S, Beaudet M, Leduc A. Constraints to partial cutting in the boreal forest of Canada in the context of natural disturbance-based management: a review. Forestry. 2013;87(1):11-28. https://doi.org/10.1093/forestry/cpt047.

90. Shorohova E, Sinkevich S, Kryshen A, Vanha-Majamaa I. Variable retention forestry in European boreal forests in Russia. Ecol Process. 2019;8(1):34. https://doi.org/10.1186/ s13717-019-0183-7.

91. Xu H, Li Y, Liu S, Zang R, He F, Spence JR. Partial recovery of a tropical rain forest a half-century after clear-cut and selective logging. J Appl Ecol. 2015;52(4):1044-52. https://doi.org/10. 1111/1365-2664.12448.

92. Lee J, Morrison IK, Leblanc J-D, Dumas MT, Cameron DA. Carbon sequestration in trees and regrowth vegetation as affected by clearcut and partial cut harvesting in a second-growth boreal mixedwood. For Ecol Manag. 2002;169(1):83-101. https://doi. org/10.1016/S0378-1127(02)00300-6.

93. ••Montoro Girona M, Lussier J-M, Morin H, Thiffault N. Conifer regeneration after experimental shelterwood and seed-tree treatments in boreal forests: finding silvicultural alternatives. Front Plant Sci. 2018;9:1145 This study evaluates the effect of partial cutting intensity and form on the regeneration process for 10 years after harvesting in the boreal forests. It confirms that shelterwood and seed-tree harvesting combined with scarification as viable silvicultural alternatives to clear-cutting to maintain adequate regeneration in black spruce stands.

94. Eliasson P, Svensson M, Olsson M, Ågren GI. Forest carbon balances at the landscape scale investigated with the $\mathrm{Q}$ model and the CoupModel-responses to intensified harvests. For Ecol Manag. 2013;290:67-78.

95. Carroll M, Milakovsky B, Finkral A, Evans A, Ashton MS. Managing carbon sequestration and storage in temperate and boreal forests. In: Ashton MS, Tyrrell ML, Spalding D, 
Gentry B, editors. Managing forest carbon in a changing climate. Dordrecht: Springer, Netherlands; 2012. p. 205-26.

96. Hoover C, Stout S. The carbon consequences of thinning techniques: stand structure makes a difference. J For. 2007;105(5):266-70.

97. Barbour RJ, Fayle DCF, Chauret G, Cook J, Karsh MB, Ran S. Breast-height relative density and radial growth in mature jack pine (Pinus banksiana) for 38 years after thinning. Can J For Res. 1994;24(12):2439-47.

98. D'Amore DV, Oken KL, Herendeen PA, Steel EA, Hennon PE. Carbon accretion in unthinned and thinned young-growth forest stands of the Alaskan perhumid coastal temperate rainforest. Carbon Balance Manag. 2015;10(1):25. https://doi.org/10.1186/ s13021-015-0035-4.

99. • Ruiz-Peinado R, Oviedo JAB, Senespleda EL, Oviedo FB, del Río Gaztelurrutia M. Forest management and carbon sequestration in the Mediterranean region: a review. For Syst. 2017;26(2):10 This paper is related to our review. It assesses the main effects of forest management by comparing the effects of silvicultural systems (even-aged vs. uneven-aged stands, coppice systems, agroforestry systems), silvicultural options (thinning, rotation period, species composition), afforestation and harvesting on $\mathrm{C}$ sequestration in the Mediterranean area.

100. Ruano I, Rodríguez-García E, Bravo F. Effects of pre-commercial thinning on growth and reproduction in post-fire regeneration of Pinus halepensis Mill. Ann For Sci. 2013;70(4):357-66. https://doi.org/10.1007/s13595-013-0271-2.

101. Campbell J, Alberti G, Martin J, Law BE. Carbon dynamics of a ponderosa pine plantation following a thinning treatment in the northern Sierra Nevada. For Ecol Manag. 2009;257(2):453-63.

102. Concilio A, Siyan M, Qinglin L, et al. Soil respiration response to prescribed burning and thinning in mixed-conifer and hardwood forests. Can J For Res. 2005;35(7):1581-91.

103. Tarroux E, DesRochers A, Krause C. Effect of natural root grafting on growth response of jack pine (Pinus banksiana) after commercial thinning. For Ecol Manag. 2010;260(4):526-35. https://doi.org/10.1016/j.foreco.2010.05.008.

104. Amiro BD et al. Ecosystem carbon dioxide fluxes after disturbance in forests of North America. J Geophys Res Biogeosci. 2010;115(G4). https://doi.org/10.1046/j.1365-3040.1999. 00453.x

105. Lindo Z, Visser S. Microbial biomass, nitrogen and phosphorus mineralization, and mesofauna in boreal conifer and deciduous forest floors following partial and clear-cut harvesting. Can J For Res. 2003;33(9):1610-20.

106. Keenan RJ, Kimmins JP. The ecological effects of clear-cutting. Environ Rev. 1993;1(2):121-44.

107. Covington WW. Changes in forest floor organic matter and nutrient content following clear cutting in northern hardwoods. Ecology. 1981;62(1):41-8. https://doi.org/10.2307/1936666.

108. •Montoro Girona M, Morin H, Lussier J-M, and Ruel J-C. Post-cutting mortality following experimental silvicultural treatments in unmanaged boreal forest stands. Front For Glob Change. 2019;2(4). https://doi.org/10.3389/ffgc.2019.00004.

This study examines the success of partial cutting as an alternative method to ensure the sustainable management of boreal forests, 10 years after various experimental shelterwood and seed-tree cuttings, in unmanaged even-aged black spruce stands.

109. Taylor AR, Wang JR, Kurz WA. Effects of harvesting intensity on carbon stocks in eastern Canadian red spruce (Picea rubens) forests: an exploratory analysis using the CBM-CFS3 simulation model. For Ecol Manag. 2008;255(10):3632-41. https://doi.org/ 10.1016/j.foreco.2008.02.052.

110. Peng C, Jiang H, Apps MJ, Zhang Y. Effects of harvesting regimes on carbon and nitrogen dynamics of boreal forests in central Canada: a process model simulation. Ecol Modell. 2002;155(2-3):177-89.

111. Navarro FB, Jiménez MN, Cañadas EM, Gallego E, Terrón L, Ripoll MA. Effects of different intensities of overstory thinning on tree growth and understory plant-species productivity in a semi-arid Pinus halepensis Mill. Afforrestation. For Syst. 2010;19(3):410-7.

112. Montoro Girona M, Morin H, Lussier J-M, Walsh D. Radial growth response of black spruce stands ten years after experimental shelterwoods and seed-tree cuttings in boreal forest. Forests. 2016;7(12):240. https://doi.org/10.3390/f7100240.

113. Chan SS, Larson DJ, Maas-Hebner KG, Emmingham WH, Johnston SR, Mikowski DA. Overstory and understory development in thinned and underplanted Oregon Coast Range Douglas-fir stands. Can J For Res. 2006;36(10):2696-711.

114. Øyen B, Nilsen P. Growth effects after mountain forest selective cutting in southeast Norway. Forestry. 2002;75(4):401-10.

115. Wallentin C, Nilsson U. Storm and snow damage in a Norway spruce thinning experiment in southern Sweden. Forestry. 2013;87(2):229-38. https://doi.org/10.1093/forestry/cpt046.

116. -Moussaoui L, Leduc A, Girona MM, et al. Success factors for experimental partial harvesting in unmanaged boreal forest: 10-year stand yield results. Forests. 2020;11(11):1199 This paper assesses the effects of partial harvesting on stand development (recruitment, growth and mortality). Also, it underlines the pre-existing structure and site characteristics in the selection of management strategies to maximize the potential of partial harvesting to achieve sustainable forest management.

117. Nave LE, Vance ED, Swanston CW, Curtis PS. Harvest impacts on soil carbon storage in temperate forests. For Ecol Manag. 2010;259(5):857-66.

118. Yanai RD, Currie WS, Goodale CL. Soil carbon dynamics after forest harvest: an ecosystem paradigm reconsidered. Ecosystems, Springer. 2003;6(3):197-212. http://www.jstor.org/stable/ 3658887

119. Økland T, et al. Short-term effects of whole-tree harvesting on understory plant species diversity and cover in two Norway spruce sites in southern Norway. Scand J Forest Res. 2016;31(8):766-776. https://doi.org/10.1080/02827581.2016. 1164889

120. Sun X, Tang Z, Ryan MG, You Y, Sun OJ. Changes in soil organic carbon contents and fractionations of forests along a climatic gradient in China. For Ecosyst. 2019;6(1):1-12.

121. Smith P, Fang C, Dawson JJC, Moncrieff JB. Impact of global warming on soil organic carbon. Adv Agron. 2008;97:1-43.

122. Boisvenue C, Bergeron Y, Bernier P, Peng C. Simulations show potential for reduced emissions and carbon stocks increase in boreal forests under ecosystem management. Carbon Manag. 2012;3(6):553-68. https://doi.org/10.4155/cmt.12.57.

123. Liski J, Pussinen A, Pingoud K, Mäkipää R, Karjalainen T. Which rotation length is favourable to carbon sequestration? Can J For Res. 2001;31(11):2004-13.

124. Pérez-Cruzado C, Mansilla-Salinero P, Rodríguez-Soalleiro $\mathrm{R}$, Merino A. Influence of tree species on carbon sequestration in afforested pastures in a humid temperate region. Plant Soil. 2012;353(1-2):333-53.

125. Cooper CF. Carbon storage in managed forests. Can J For Res. 1983;13(1):155-66.

126. Parajuli R, Chang SJ. Carbon sequestration and uneven-aged management of loblolly pine stands in the Southern USA: a joint optimization approach. For Policy Econ. 2012;22:65-71.

127. Nilsen P, Strand LT. Carbon stores and fluxes in even-and uneven-aged Norway spruce stands. Silva Fenn. 2013;47(4):1-15.

128. Seidl R, Rammer W, Lasch P, Badeck F-W, Lexer M. Does conversion of even-aged, secondary coniferous forests affect carbon sequestration? A simulation study under changing environmental 
conditions. Silva Fenn. 2008;42:369-86. https://doi.org/10. 14214/sf.243.

129. Nunery JS, Keeton WS. Forest carbon storage in the northeastern United States: net effects of harvesting frequency, post-harvest retention, and wood products. For Ecol Manag. 2010;259(8):1363-75.

130. Laiho O, Lähde E, Pukkala T. Uneven- vs even-aged management in Finnish boreal forests. Forestry. 2011;84(5):547-55. https://doi.org/10.1093/forestry/cpr032.

131. Pukkala T, Lähde E, Laiho O, Salo K, Hotanen J-P. A multifunctional comparison of even-aged and uneven-aged forest management in a boreal region. Can J For Res. 2011;41(4):851-62.

132. Metsaranta JM, Kurz WA, Neilson ET, Stinson G. Implications of future disturbance regimes on the carbon balance of Canada's managed forest (2010-2100). Tellus B Chem Phys Meteorol. 2010;62(5):719-28.

133. Naeem S, Thompson LJ, Lawler SP, Lawton JH, Woodfin RM. Declining biodiversity can alter the performance of ecosystems. Nature. 1994;368(6473):734.

134. Tilman D, Knops J, Wedin D, Reich P, Ritchie M, Siemann E. The influence of functional diversity and composition on ecosystem processes. Science. 1997;277(5330):1300-2.

135. Erskine PD, Lamb D, Bristow M. Tree species diversity and ecosystem function: can tropical multi-species plantations generate greater productivity. For Ecol Manag. 2006;233(2-3):205-10.

136. Wang Q, Wang S, Fan B, Yu X. Litter production, leaf litter decomposition and nutrient return in Cunninghamia lanceolata plantations in south China: effect of planting conifers with broadleaved species. Plant Soil. 2007;297(1):201-11. https://doi. org/10.1007/s11104-007-9333-2.

137. Rothe A, Binkley D. Nutritional interactions in mixed species forests: a synthesis. Can J For Res. 2001;31(11):1855-70.

138. Dawud S, Raulund-Rasmussen K, Domisch T, Finér L, Jaroszewicz B, Vesterdal L. Is tree species diversity or species identity the more important driver of soil carbon stocks, $\mathrm{C} / \mathrm{N}$ ratio, and pH? Ecosystems. 2016;19:1-16. https://doi.org/10.1007/ s10021-016-9958-1.

139. •Cavard X, Bergeron Y, Chen HYH, Pare D. Mixed-species effect on tree aboveground carbon pools in the east-central boreal forests. Can J For Res. 2010;40(1):37-47 This study investigates the potential of mixed forest stands as better aboveground carbon sinks than pure stands.

140. Pretzsch H, Block J, Dieler J, et al. Comparison between the productivity of pure and mixed stands of Norway spruce and European beech along an ecological gradient. Ann For Sci. 2010;67(7):712.

141. Légaré S, Paré D, Bergeron Y. The responses of black spruce growth to an increased proportion of aspen in mixed stands. Can J For Res. 2004;34(2):405-16.

142. Del Río M, et al. Characterization of the structure, dynamics, and productivity of mixed-species stands: review and perspectives. Eur J For Res. 2016;135(1):23-49.

143. van der Werf GR, et al. $\mathrm{CO}_{2}$ emissions from forest loss. Nat Geosci. 2009;2(11):737-8. https://doi.org/10.1038/ngeo671.

144. $\bullet$ Luyssaert S, Schulze ED, Börner A, et al. Old-growth forests as global carbon sinks. Nature. 2008;455(7210):213-5 This paper reports a search of literature and databases for forest carbon flux, and it estimates and demonstrates that old-growth forests can continue to accumulate carbon, contrary to the longstanding view that they are carbon neutral.

145. Alongi DM. Carbon sequestration in mangrove forests. Carbon Manag. 2012;3(3):313-22. https://doi.org/10.4155/cmt.12.20.

146. •McGarvey JC, Thompson JR, Epstein HE, Shugart HH Jr. Carbon storage in old-growth forests of the Mid-Atlantic: toward better understanding the eastern forest carbon sink. Ecology. 2015;96(2):311-7. https://doi.org/10.1890/14-1154.1 This paper highlights the importance of old-growth forests and demonstrates the potential for dead wood to maintain the sink capacity of secondary forests for many decades to come.

147. Xu CY, Matthew H, Turnbull DT, et al. Age-related decline of stand biomass accumulation is primarily due to mortality and not to reduction in NPP associated with individual tree physiology, tree growth or stand structure in a Quercus-dominated forest. J Ecol. 2012;100(2):428-40. https://doi.org/10.1111/j.1365-2745. 2011.01933.x.

148. Schulze E-D, Wirth C, Heimann M. Managing forests after Kyoto. Science. 2000;289(5487):2058-9.

149. Wang W, Lei X, Ma Z, Kneeshaw DD, Peng C. Positive relationship between aboveground carbon stocks and structural diversity in spruce-dominated forest stands in New Brunswick, Canada. For Sci. 2011;57(6):506-15.

150. Agee JK, Skinner CN. Basic principles of forest fuel reduction treatments. For Ecol Manag. 2005;211(1):83-96. https://doi.org/ 10.1016/j.foreco.2005.01.034.

151. Post WM, Kwon KC. Soil carbon sequestration and landuse change: processes and potential. Glob Change Biol. 2000;6(3):317-27.

152. Pötzelsberger E, Hasenauer H. Soil change after 50 years of converting Norway spruce dominated age class forests into single tree selection forests. For Ecol Manag. 2015;338:176-82.

153. Peng Y, Thomas SC, Tian D. Forest management and soil respiration: implications for carbon sequestration. Environ Rev. 2008;16:93-111.

154. Rannik Ü, et al. Fluxes of carbon dioxide and water vapour over Scots pine forest and clearing. Agric For Meteorol. 2002;111:187-202. https://doi.org/10.1016/S0168-1923(02) 00022-9.

155. Strukelj M, Brais S, Paré D. Nine-year changes in carbon dynamics following different intensities of harvesting in boreal aspen stands. Eur J For Res. 2015;134(5):737-54

156. Smeets EMW, Faaij APC. Bioenergy potentials from forestry in 2050. Clim Change. 2007;81(3):353-90. https://doi.org/10.1007/ s10584-006-9163-x

157. Kurz WA, Dymond CC, White TM, et al. CBM-CFS3: a model of carbon-dynamics in forestry and land-use change implementing IPCC standards. Ecol Modell. 2009;220(4):480-504.

158. Seymour RS and Hunter ML, New forestry in eastern spruce-fir forests: principles and applications to Maine. College of Forest Resources, University of Maine, Orono, ME, USA. 1992; vol. 716.

159. D'Amato AW, Palik BJ. Building on the last 'new' thing: exploring the compatibility of ecological and adaptation silviculture. Can J For Res. 2020. https://doi.org/10.1139/cjfr-2020-0306.

160. Messier C, Tittler R, Kneeshaw DD, et al. TRIAD zoning in Quebec: experiences and results after 5 years. For Chron. 2009;85(6):885-96.

161. Henneb M, Thiffault N, Valeria O. Regional climate, edaphic conditions and establishment substrates interact to influence initial growth of black spruce and jack pine planted in the boreal forest. Forests. 2020;11(2):139. https://doi.org/10.3390/f1102 0139.

162. Nichols JD, Bristow M, Vanclay JK. Mixed-species plantations: prospects and challenges. For Ecol Manag. 2006;233(2):383-90. https://doi.org/10.1016/j.foreco.2006.07.018.

163. Merlo M, Rojas Briales E. Public goods and externalities linked to Mediterranean forests: economic nature and policy. Land Use Policy. 2000;17(3):197-208. https://doi.org/10.1016/S02648377(00)00017-X.

Publisher's Note Springer Nature remains neutral with regard to jurisdictional claims in published maps and institutional affiliations. 